\title{
An Overview on Coronary Heart Disease (A Comparative Evaluation of Turkey and Europe) and Cost-effectiveness of Diagnostic Strategies
}

\author{
Koroner Kalp Hastalığına Genel Bakış (Türkiye ile Avrupa Arasında Bir Karşılaştırma) \\ ve Tanısal Stratejilerin Maliyet Etkinliği
}

\author{
Cengiz Taş̧̧ı, Nihat Özçelik \\ Gama Tip Merkezi, Nükleer Tip Bölümü, Gaziantep, Turkey
}

\begin{abstract}
Objective: Coronary heart disease (CHD) is the leading cause of death for men and women in Turkey as it is in Europe and US. The prevalence of the disease is $3.8 \%$ in Turkey and 200,000 patients are added to the pool of CHD annually. Because of genetic predisposition and high proportions of physical inactivity, smoking habit, and obesity, CHD is encountered in earlier ages in our country. So, the economic burden of the disease is expected to be relatively high, but the amount of health expenditure is not always parallel to the prevalence of a disease in the community. This article was written to overview CHD statistics to make a comparison between Turkey and some European countries and to investigate the value of myocardial perfusion scan (MPS) as a gatekeeper in diagnosing CHD before invasive coronary angiography (ICA). The consequences were evaluated for Turkey. In diagnosis; noninvasive testing gains importance in connection with the new approaches in treatment strategies, because a direct ICA strategy results in higher rates of revascularization without improvement in clinical outcomes. A "gatekeeper" is needed to select the patients who are not required to undergo angiography. MPS with its proved power in diagnosis and predicting prognosis, provides a cost-effective solution, and is accepted in some extensive analyses as a "gatekeeper" particularly in intermediate and high risk patients and in patients with known CHD. In conclusion, MPS may provide an optimal solution better than the ongoing situation in Turkey as well, when it is approved as a "gatekeeper in an algorithm before ICA. (MIRT 2011;20:75-93)
\end{abstract}

Key words: Coronary heart disease, cardiac noninvasive testing, cost-effectiveness, myocardial perfusion scan

\section{Özet}

Amaç: Koroner kalp hastalığı (KKH), Avrupa'da ve Amerika'da olduğu gibi Türkiye'de de kadın ve erkekler arasında önde gelen ölüm sebebidir. Ülkemizde hastalığın prevalansı \%3.8'dir ve her yıl KKH havuzuna ortalama 200000 hasta eklenmektedir. Türkiye'de daha genç yaşlarda iskemik kalp hastalığına rastlanmaktadır. Türklerin genetik yatkınlığının yanı sıra, toplumumuzda günlük egzersiz alışkanı̆̆ının az olması, sigara alışkanlığı ve obezitenin yüksek oranda bulunması gibi nedenler, KKH'nın erken yaşlarda görülmesini etkilemektedir. Hastalığa ayrılan sağlık harcamasının da görece yüksek olması beklenebilir, ancak bir hastalık için yapılan toplam ya da kişi başı sağlık harcaması her zaman o hastalığın toplumdaki prevalansı ile paralel değildir. Bu çalışmada, Türkiye ile bazı Avrupa ülkeleri arasında KKH istatistikleri açısından bir karşılaştırma yapıldı ve miyokard perfüzyon sintigrafisi (MPS)"nin koroner anjiyografi öncesinde bir eleyici test olarak kullanılmasının klinik ve ekonomik sonuçları incelendi. Bu sonuçlar ülkemiz açısından da değerlendirildi. Tedavi stratejilerindeki yeni yaklaşımlara paralel olarak revaskülarizasyondan yarar görebilecek yüksek riskli hastaları seçmek için girişimsel olmayan testler önem kazanmıştır. Öte yandan, tanı için hastalara doğrudan anjiyografi yapılmasının, klinik sonuçları değiştirmediği halde yüksek oranlarda revaskülarizasyona yol açtığı görüldüğünden, hasta seçiminde eleyici bir öncü teste ihtiyaç ortaya çıkmıştır. Klinik sonuçları en iyi öngörebilen ekonomik bir test olması dolayısıyla, MPS literatürde, özellikle orta ve yüksek riskli hastalar ile bilinen KKH olanlarda böyle bir rol için önerilmektedir. Anjiyografi öncesinde bir eleyici test olarak kabul edilmesi halinde, MPS Türkiye'de de klinik ve ekonomik sonuçlar açısından mevcut duruma göre daha iyi bir çözüm sağlayabilir. (MIRT 2011;20:75-93)

Anahtar kelimeler: Koroner kalp hastalığı, tanısal testler, maliyet etkinlik analizi, miyokard perfüzyon sintigrafisi 


\section{Introduction}

\section{The Prevalence and the Incidence of CHD in Europe and Turkey}

Coronary heart disease $(C H D)$ is an important health problem in Turkey as it is in Europe and US, because it is the leading cause of death for men and women, and it causes substantial disability and loss of productivity $(1,2,3,4,5)$. The World Health Organization (WHO) assessments about 15 leading causes of death worldwide had indicated that ischemic heart disease would move from number five position in 1990 to number one position in $2020(2,4)$. This estimation was first made in 1996, but the recent studies evaluating the global burden of disease (last updated for 2004) revealed that this had become already a fact particularly in the developed and developing countries $(6,7,8)$. According to the WHO projections, the number of deaths due to $\mathrm{CHD}$ will increase in the future all over the world. This trend is expected to continue for the next 30 years (8) (Figure 1).

European cardiovascular disease (CVD) statistics indicate that CHD by itself is the most common cause of death in Europe and in European Union (EU) (Figure 2). 1.92 million deaths ( $21 \%$ of men and $22 \%$ of women deaths) from CHD in Europe and 741,000 deaths (16\% of men and $15 \%$ of women deaths) in EU are accounted each year. There is a marked west-east gradient in the age standardized cardiovascular mortality rates. Death rate from CHD is relatively low and decreases steadily in Northern, Southern and Western Europe, while it is high and increases in Central and Eastern Europe including Turkey. Cardiovascular mortality rates for women are lower than those for men in all European countries $(3,9,10,11,12)$ (Figure 3$)$.

"Turkey Burden of Disease Study, 2004" by Refik Saydam Hygiene Center (RSHC) on behalf of the Ministry of Health and TEKHARF Studies by A. Onat et al. also confirm that ischemic heart disease is the leading cause of death in Turkey $(1,13,14,15)$ (Table 1$)$. CHD is responsible for $20.7 \%$ of male, and $22.9 \%$ of female deaths $(21.7 \%$ of all) (1). These numbers are very close to the average of Europe, but higher than the average of $\mathrm{EU}(3,9,10,11,12,15)$. As it is in the other Eastern European Countries, CHD rates increase each year in Turkey $(13,14,15)$. The prevalence of the disease in individuals over 50 years old was found to be increased by $80 \%$ in 2007 2008 TEKHARF study, when compared to the study in 1990

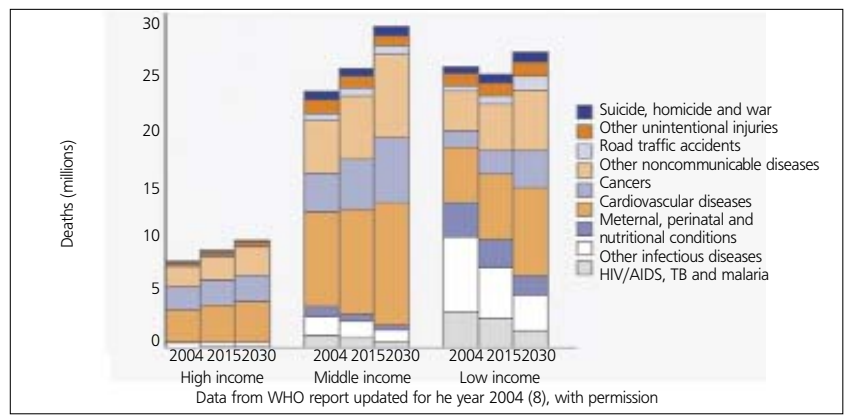

Figure 1. Deaths by cause for high-, middle and low-income countries in the future
(15). The total prevalence is $3.8 \%$ (4.1\% in males and $3.5 \%$ in females). There were approximately 1 million patients in 1990 and the number reached 3.1 million up to 2008. 390 000 new coronary artery events and 190000 deaths are encountered each year. This means that 200000 patients are added to the pool of CHD yearly (15) (Figure 4). Coronary mortality rate in 45-74 year-old individuals is reported as $0.57 \%(0.76 \%$ in males and $0.38 \%$ in females) between $1990-2008$ and a decreasing trend in rising rates was recorded between 2000-2008 $(15,16)$.

In an European analysis in 2000 that did not include Russia and Ukraine, the annual mortality from CHD in 45-74 years of age was found highest in Turkish women and second highest in Turkish men after Latvians (Figure 3). Coronary mortality rates are approximately 3 times more in Turkish men and 5 times more in Turkish women than those in Western Europe $(15,16,17)$.

CHD is encountered in earlier ages in Turkey. The prevalence of the disease is about $6 \%$ in $45-54$ year-old individuals, which is considered to be relatively high for this age population (15). Every ten years of aging increases the risk of CHD 1.8 fold in men and 1.9 fold in women (18). Actually, Turkey is a unique country with its young population among European countries. Population over 65 years old $(65+)$ was $5.8 \%$ in 2008 , while the average of European countries was $15.3 \%$ (Table 2). Since the age is the most important independent risk factor (18) and CHD is seen generally in elder people over 65 years old $\left(65^{+}\right)$, it is surprising that CHD is the first cause of death in Turkey as it is in the developed countries with aged populations. 2009 statistics by Turkish Ministry of Health indicated that population aged 65+ was $4.3 \%$ in 1990, $5.7 \%$ in $2000,6.7 \%$ in 2008 (not age-standardized), and $7.0 \%$ in 2009 (19). Very far off from the rates in Europe but the statistics indicate an increase in elder people in Turkish population probably because the average life and life expectancy is getting longer due to advanced treatment options. On the other hand, CHD is a complex disorder resulting from many risk factors. Genetic predisposition for atherosclerosis is a substantial risk for developing CHD especially at early ages. Turkish adults -both men and womenhave the lowest levels of total cholesterol (TC) and HDL-C among the citizens of all European countries (Table 3). Several comparative studies including Turks living in Germany and US confirm that HDL-C levels in Turks are among the lowest in the

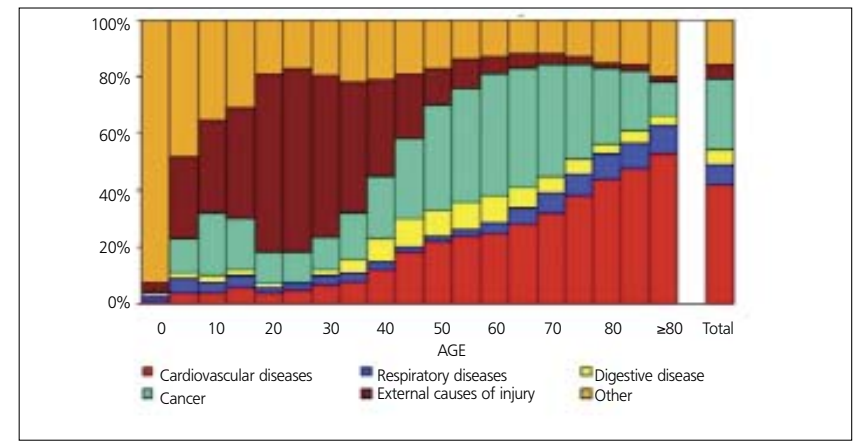

Figure 2. Major causes of death by age in Europe from Euro Heart survey $2006(9)$ 
world. Therefore, the ratio of TC/HDL-C, the best independent lipid predictor of CHD, is very high in Turkish adults. Low levels of TC, LDL-C and HDL-C are associated with high levels of hepatic lipase, fasting triglycerides and high levels of apolipoprotein-B $(20,21,22,23,24)$. This lipid profile pointing out a genetic disorder constitutes a significant early predisposition to CHD.

Positively, the percentage of total energy available from fat is relatively low in Turkish people and the average amount of fruit and vegetable intake per person is the second greatest in Turkey after Greece among all European countries (Table 4). There are some regional differences in diet habits ranging from the Aegean coast diet rich in olive oil to the inland

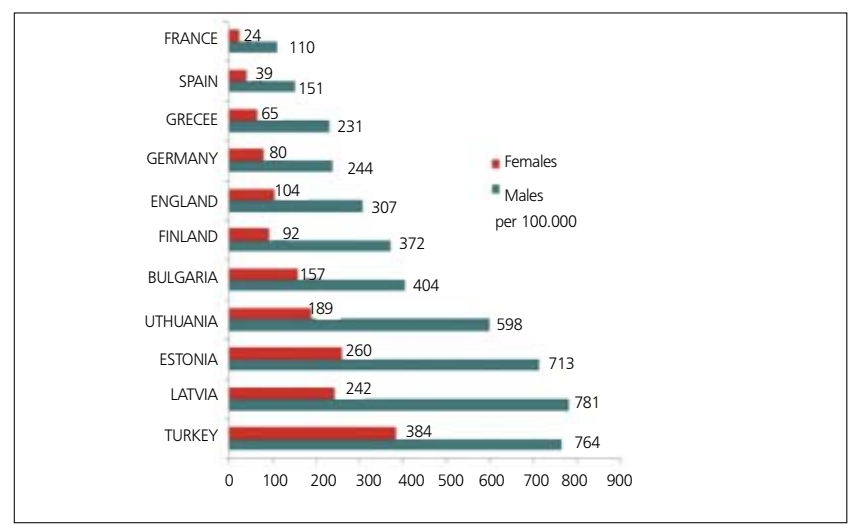

Figure 3. Age standardized mortality rates in 45-74 years old people with CHD in Europe, 2000 (15-17). Modified from Ref 15

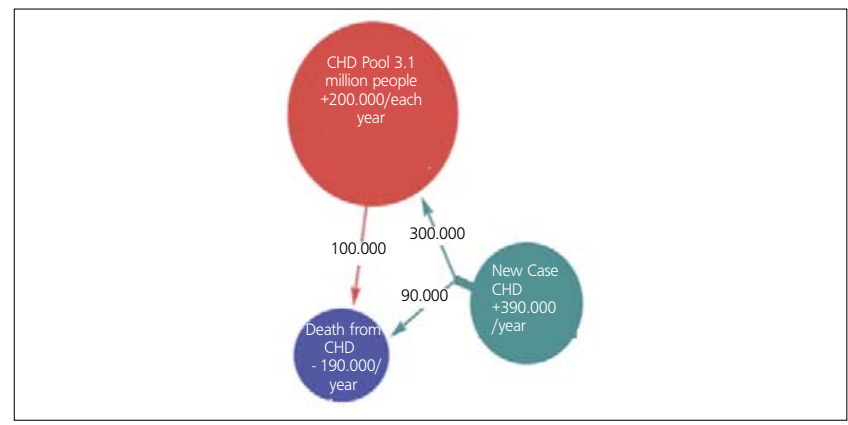

Figure 4. Patient population, new cases and death from CHD in Turkish adults (15). With permission of $A$. Onat

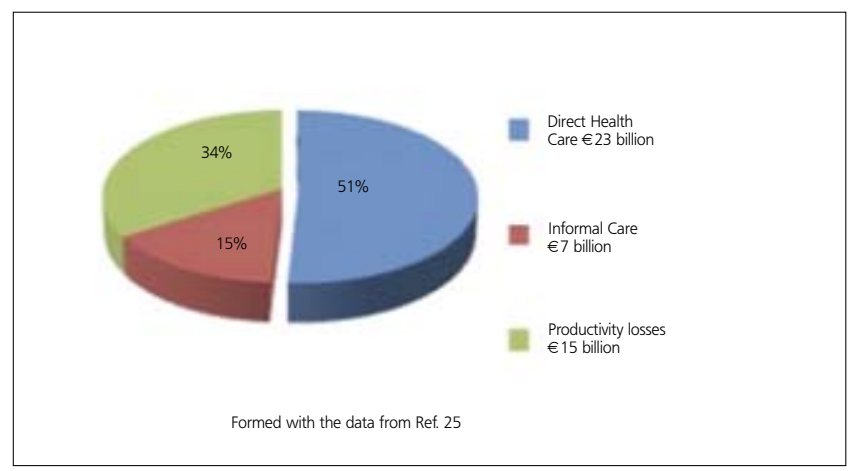

Figure 5. Economic burden of CHD in EU, in 2003 (Overall cost is $€ 49$ bilion a year)
Anatolian diet rich in meat and pastry. Alcohol consumption is distinctively low in our country, so that moderate alcohol consumption reduces the risk of CHD while high level of intake increases (Table 4). But, physical inactivity common in both genders, smoking habit especially in men and obesity highest in Turkish women in Europe result in HT, diabetes, metabolic syndrome and finally a high prevalence of CHD (Table 3). All these factors probably are the reasons of unanticipated fact that Turkish adults have the pattern of death causes similar to the population of developed countries (20). In paralel to these predispositions, TEKHARF studies indicate that Framingham risk scoring when applied to the Turkish adults underestimates the risks in reality, because the absolute coronary event risk is much higher in Turkey (18).

\section{Economic Burden of CHD}

CHD is estimated to cost the EU economy $€ 49$ billion a year, about $2.6 \%$ of total healthcare expenditure. CHD healthcare cost per capita is about $€ 50$ in $\mathrm{EU}$, when purchasing power parity (PPP) is used (25) (Table 5). Of the total cost of CHD in EU, about $48 \%$ is due to direct health care costs, $34 \%$ to productivity losses and $18 \%$ to the informal care costs. Of the total direct healthcare costs, about $62 \%$ is due to inpatient care, $23 \%$ to medications, and remaining $16 \%$ to primary care, outpatient care and accident \& emergency (25) (Figure 5,6).

Unfortunately, there is no data available about diseasespecific costs in Turkey, but some projections may be done for the economic burden of CHD using data from EU. According to an analysis of Europe in 2002 (12), Estonia, Latvia, Lithuania, Hungary, Romania and Bulgaria seem to be the closest countries to Turkey in terms of age-standardized disability-adjusted life years (DALYs) rate for CHD (Table 2, Figure 7,8). DALYs for a specific disease are calculated as the sum of the years of life lost due to premature mortality (YLL) and the years lost due to disability (YLD) (6). One DALY is defined as the loss of one year of equivalent full health. So, DALYs rate represents the consequences of morbidity and

Table 1. Ten Leading Causes of Death (Turkey, 2004)

\begin{tabular}{lcc}
\hline Causes of Death & $\begin{array}{c}\text { Number } \\
\text { of Deaths }\end{array}$ & $\begin{array}{c}\text { Percent } \\
\text { Total }\end{array}$ \\
\hline 1. Ischemic Heart Disease & 93.260 & 21.7 \\
2. Cerebrovascular Disease & 64.780 & 15.0 \\
3. COPD & 25.104 & 5.8 \\
4. Perinatal Causes & 24.756 & 5.8 \\
5. Lower Respiratory Infections & 18.225 & 4.2 \\
6. Hypertensive Heart Disease & 12.805 & 3.0 \\
7. Trachea, bronchus and & 11.586 & 2.7 \\
lung cancers & & \\
8. Diabetes Mellitus & 9.548 & 2.2 \\
9. Road Traffic Accidents & 8.395 & 2.0 \\
10. Inflammatory Heart Diseases & 7.992 & 1.9 \\
\hline Data from TURKEY BURDEN OF DISEASE STUDY 2004 (1). With permission \\
of RSHC
\end{tabular}


mortality from a disease together. Mortality rates from CHD are not always parallel to the DALYs rates, that's why not mortality rates alone but DALY's rates for CHD may be expected to have correlation with total or per capita health expenditure on CHD. As it is expected, J. Leal et al., found no direct correlation between CVD-related health expenditure and mortality rates or life expectancy (25). Anyway, coronary mortality rates are close in these seven low-income countries and the rates are higher than those in high-income countries in Europe (Table 2, Figure 8). Life expectancy, the second lowest in Turkish population after Ukrainians, is also similar in these seven countries. In the same study by J. Leal et al., a strong positive correlation was indicated between CVDrelated health expenditure and national income. The Gross National Income per capita (GNIpc) and the total health expenditure per capita in these seven countries are close, too (Table 5, Figure 9). Hospital discharge from CHD is found uncorrelated to the other parameters (Table 2). Turkey seems to be in the same class with these six Eastern European countries in terms of GNIpc, total health expenditure per capita and age standardized DALYs rate for CHD. So, the average cost per capita on CHD may be expected to be similar in this group of countries and estimated about $€ 20$ (PPP€) as the average of 4 of 7 countries calculated from the same study for the year 2003. (Table 5). This may roughly represent the average per person in Turkey, too.

\section{Diagnostic Strategies in Stable CHD in Connection with the Treatment Strategies}

\section{Understanding the Biology of CHD}

$\mathrm{CHD}$ is a general term for atherosclerosis in the coronary vessels and it appears in various stages. Fatty material and other substances form a plaque on the walls of the vessels.

Table 2. CHD related statistics in some European countries

\begin{tabular}{|c|c|c|c|c|c|c|}
\hline & $\begin{array}{l}\text { Life expectancy } \\
\text { at birth, } \\
2008 \text { (years) }\end{array}$ & $\begin{array}{l}\text { Life expectancy } \\
\text { at age 65, } \\
2008 \text { (years) }\end{array}$ & $\begin{array}{c}\% \text { of population } \\
\text { aged } 65+ \\
2008(\%)\end{array}$ & $\begin{array}{c}\text { Death rates } \\
\text { from CHD }(45-74 \text { y), } \\
2000 \text { per } 100,000\end{array}$ & $\begin{array}{c}\text { DALYs rate } \\
\text { of CHD (45-74 y) } \\
2005 \text { per } 100,000\end{array}$ & $\begin{array}{l}\text { Hospital discharges } \\
\text { from CHD, } 2008 \\
\text { per } 100,000\end{array}$ \\
\hline Germany & $80.0^{*}$ & $19.2^{*}$ & 20.2 & 157 & 574 & 916 \\
\hline UK & 80.0 & 19.2 & 16.2 & 202 & 657 & 444 \\
\hline Finland & 80.0 & 19.7 & 16.7 & 222 & 687 & $865^{*}$ \\
\hline France & 81.4 & 21.0 & 16.6 & 65 & 259 & 497 \\
\hline Spain & 81.5 & 20.4 & 16.6 & 92 & 368 & 302 \\
\hline Greece & 80.1 & 19.0 & 18.7 & 144 & 620 & $970 *$ \\
\hline Estonia & 74.3 & 16.9 & 17.2 & 446 & 1.449 & 999 \\
\hline Hungary & 74.2 & 16.4 & 16.3 & 343 & 1.137 & 808 \\
\hline Latvia & 72.5 & 16.0 & 17.3 & 461 & 1.606 & 1.472 \\
\hline Lithuania & 72.0 & 16.3 & 15.9 & 357 & 1.444 & 1.297 \\
\hline Romania & 73.5 & 15.8 & 14.9 & 322 & 1.176 & 367 \\
\hline Turkey & 71.9 & ** & 5.8 & 570 * & 1.332 & 524 \\
\hline Bulgaria & 73.4 & 15.3 & 17.4 & 271 & 1.344 & 1.017 \\
\hline \multicolumn{7}{|l|}{ EU } \\
\hline $\begin{array}{l}\text { European Region } \\
\text { Source }\end{array}$ & $\begin{array}{c}75.5 \\
\text { Data from } \\
\text { Who/Europe } \\
\text { database (26). } \\
\text { * } 2006\end{array}$ & $\begin{array}{c}17.4 \\
\text { Data from } \\
\text { Who/Europe } \\
\text { database (26). } \\
\text { * } 2006 \\
\text { **No data }\end{array}$ & $\begin{array}{c}15.3 \\
\text { Data from } \\
\text { Who/Europe } \\
\text { database (26). } \\
\text { Age-standardized } \\
\text { to WHO population }\end{array}$ & $\begin{array}{c}220 * * \\
\text { Data from the } \\
\text { study, } 2008 \\
\text { J. Müller-Nordhorn (17). } \\
\text { * } 1990-2008 . \\
\text { Data from the } \\
\text { study by A. } \\
\text { Onat et al. (16). } \\
\text { ** 2000, } \\
\text { Data from } \\
\text { Who/Europe } \\
\text { database (26). }\end{array}$ & $\begin{array}{l}\text { Data from } \\
\text { European CVD } \\
\text { Statistics, } \\
2008 \text { by British } \\
\text { Heart Foundation (12). } \\
\text { DALYs: Disability-adjusted } \\
\text { life years. }\end{array}$ & $\begin{array}{l}804 \\
\text { Data from } \\
\text { Who/Europe } \\
\text { database (26). } \\
\text { *2006 } \\
\text { ad }\end{array}$ \\
\hline
\end{tabular}


This chronic process narrows the coronary arteries which supply blood and oxygen to the heart muscle. The lack of oxygen causing some local changes results in myocardial ischemia presented with chest pain, myocardial infarction (MI) when a coronary artery is blocked totally and may perhaps lead to death. However CHD seems to be an obstructive disease of the main coronary vessels and the routine practice of treatment is generally based on this definition. There are some other factors influencing the clinical results like endothelial dysfunction in microvascular bed that is also linked to atherosclerosis but with no obstruction. Vasospastic angina, a hyper-contraction of smooth muscle of a coronary artery without plaque formation may lead to $\mathrm{Ml}$ or sudden death (33). The researches on syndrome $X$, microvascular angiopathy and slow coronary flow indicate that CHD symptoms may appear and stress-induced ischemia may be shown in some patients whose all major coronary vessels are proved completely open $(34,35,36)$. Such patients with severe endothelial dysfunction in the absence of obstructive CHD have also been shown to have increased cardiac events (37). Slow coronary flow is a good example indicating the importance of function more than structure, so that, contrast agent in invasive coronary angiography (ICA) moves forward slowly in some patients with angina pectoris when compared to normal individuals, although the patients have evidently normal coronary anatomy (38).

On the other hand, clinical importance of obstructive CHD is not predictable according to the degree of narrowing, because there is no direct relationship between the degree of stenosis and cardiac events (39). Some compensating mechanisms occur in low and high-degree of stenosis. In early atherosclerosis with less than $50 \%$ stenosis in the vessels, plaque development and intimal thickening increase the total vessel area (expansive remodeling) to maintain lumen size

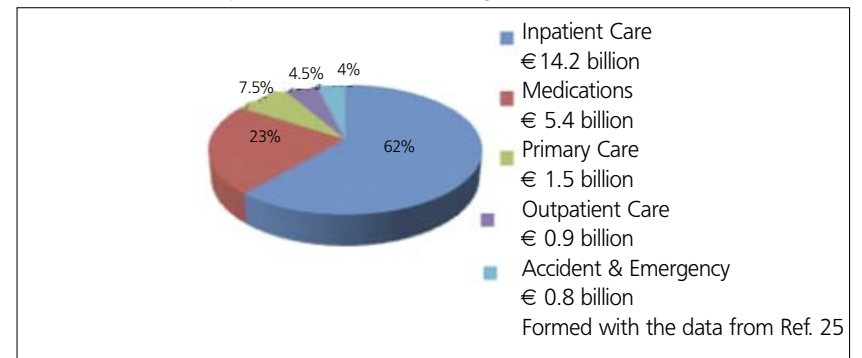

Figure 6. Direct health care cost for CHD in EU (€ 23 billion a year)

Table 3. Medical risk factors related to CHD in some European countries

\begin{tabular}{|c|c|c|c|c|c|c|}
\hline & \multirow[t]{2}{*}{$\begin{array}{l}\text { Prevalence of } \\
\text { Hypertension, } \\
2006(\%)\end{array}$} & \multicolumn{2}{|c|}{$\begin{array}{c}\text { Estimated mean } \\
\text { total cholesterol } \\
\text { levels, aged 15+, } 2010 \\
\text { (mmol/l) }\end{array}$} & \multicolumn{2}{|c|}{$\begin{array}{c}\text { Estimated prevalence } \\
\text { of obesity, adults } \\
\text { aged } 15+, 2010, \\
(\%)\end{array}$} & \multirow[t]{2}{*}{$\begin{array}{c}\text { Estimated prevalence } \\
\text { of diabetes, } \\
\text { aged } 20-79,2010 \\
(\%)\end{array}$} \\
\hline & & MEN & WOMEN & MEN & WOMEN & \\
\hline Germany & 37 & 5.6 & 5.6 & 22.9 & 26.3 & 12.0 \\
\hline UK & 31 & 5.0 & 5.0 & 23.7 & 21.3 & 4.9 \\
\hline Finland & 45 & 5.2 & 5.1 & 20.9 & 19.4 & 8.3 \\
\hline France & 36 & 5.3 & 5.2 & 9.0 & 7.6 & 9.4 \\
\hline Spain & 34 & 5.0 & 5.1 & 17.3 & 17.3 & 8.7 \\
\hline Greece & 50 & 4.7 & 4.6 & 30.3 & 26.4 & 8.8 \\
\hline Estonia & 42 & 5.0 & 5.2 & 8.6 & 8.4 & 9.9 \\
\hline Hungary & 45 & 5.4 & 5.1 & 15.8 & 16.1 & 8.8 \\
\hline Latvia & 24 & 5.3 & 5.3 & 9.7 & 15.0 & 9.9 \\
\hline Lithuania & 40 & 5.3 & 5.4 & 16.8 & 13.9 & 9.7 \\
\hline Romania & 56 & 5.1 & 5.0 & 5.5 & 12.0 & 8.4 \\
\hline Turkey & $32 *$ & 4.5 & 4.6 & 10.8 & 32.5 & 7.4 \\
\hline Bulgaria & 63 & 5.7 & 5.9 & 17.0 & 19.0 & 9.0 \\
\hline EU & 36 & & & & & \\
\hline European Region & & & & & & 8.5 \\
\hline \multirow[t]{3}{*}{ Source } & $\begin{array}{l}\text { Data from European } \\
\text { Commission 's report (27) }\end{array}$ & \multicolumn{2}{|c|}{$\begin{array}{l}\text { Data from WHO Global } \\
\text { Infobase Online (29). }\end{array}$} & \multicolumn{2}{|c|}{$\begin{array}{l}\text { Data from WHO Global } \\
\text { Infobase Online (29). }\end{array}$} & $\begin{array}{l}\text { Data from International } \\
\text { Diabetes Federation (30). }\end{array}$ \\
\hline & $\begin{array}{l}\text { *2003, Data from the study } \\
\text { (PatenT) by B. Altun et al. (28). }\end{array}$ & \multirow{2}{*}{\multicolumn{2}{|c|}{$\begin{array}{l}\text { Values are age-standardized } \\
\text { to WHO Standard Population }\end{array}$}} & \multicolumn{2}{|c|}{$\begin{array}{l}\text { Values are age-standardized } \\
\text { to WHO Standard Population }\end{array}$} & \\
\hline & & & & \multicolumn{2}{|c|}{$\begin{array}{l}\text { (Obese defined as } \\
\mathrm{BMI} \geq 30 \mathrm{~kg} / \mathrm{m}^{2} \text { ) }\end{array}$} & \\
\hline
\end{tabular}


and blood flow (40). Expansive remodeling despite its role to prevent ischemia is linked to plaque vulnerability and acute coronary syndromes (ACSs) like unstable angina, MI or sudden death. Over time, this positive remodeling becomes insufficient and is replaced with constrictive (or negative) remodeling. Constrictive remodeling is associated with much severe stenosis limiting blood flow and results in ischemia and stable angina presenting a relatively stable situation despite more progression in atherosclerotic pathway (40). Unfortunately, vulnerable plaques are generally asymptomatic, non-obstructive lesions that may rupture abruptly; therefore they are responsible for over $50 \%$ of cases of sudden death and acute MI (41). The content of vulnerable plaques is the reason for their unstable character. They are the soft plaques covered by a thin fibrous cap and include a large lipid core within a large amount of cholesterol esters and abundant macrophages indicating active inflammation. Severe stenotic plaques (narrowing $>80 \%$ of the lumen) are more fibrotic and stable which are covered by a thick fibrous cap including less lipid core and macrophages, but more vessel smooth cells, collagen fibers and calcification (42). Both plaques usually exist together in a patient, and any imaging method even ICA, a gold standard in defining the degree of obstruction, tells us very little about which plaque may be responsible of future cardiac events $(43,44)$. Finally in late atherosclerosis, chronic ischemia triggers new blood vessel growth to restore blood flow and oxygen supply to the affected areas like rendering a non-surgical natural by-pass (45). Because $\mathrm{Ml}$ frequently develops from previously non-severe $(<50 \%)$ lesions, artificial revascularization therapies targeting severe stenotic plaques do not help prevent the cardiac events when there are vulnerable plaques at the same time $(46,47)$. Furthermore, some studies (CASS, ACME, AVERT, RITA-2, COURAGE and BARI 2D) comparing medical and surgical treatment strongly emphasize that coronary revascularization beyond optimal medical therapy may offer no substantial prognostic improvement in stable patients (48) (Table 6). All these conclusions indicate that $\mathrm{CHD}$ is not a simple disease of narrowed coronary arteries.

\section{Treatment Strategies}

Treatment strategies in managing stable CHD patients are controversial and still discussed in several studies $(49,50,51,52,53,54,55,56,57,58,59,60,61,62,63,64,65$,

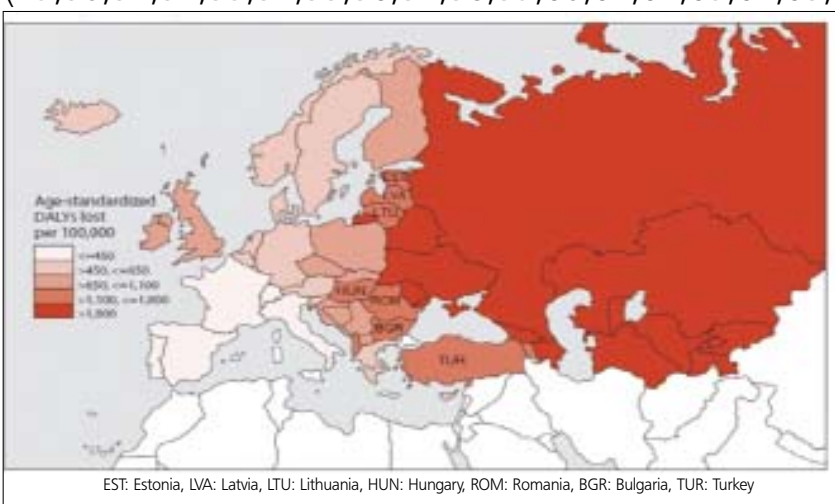

Figure 7. Age-standardized DALYs rate for CHD, 2002, Europe (11)

Table 4. Behavioral risk factors related to CHD in some European countries

\begin{tabular}{|c|c|c|c|c|c|c|}
\hline & & $\begin{array}{c}\text { Prevalence of regular } \\
\text { daily smokers, } \\
\text { aged } 15+, \text { latest } \\
\text { available year }(\%)\end{array}$ & $\begin{array}{c}\text { Average amount } \\
\text { of fruits and vegetable, } \\
2007 \text { / person/year } \\
\text { (kg) }\end{array}$ & $\begin{array}{c}\% \text { of total energy } \\
\text { from fat } \\
(\%)\end{array}$ & $\begin{array}{c}\% \text { of adults not doing } \\
\text { moderate-intensity } \\
\text { physical activity in a } \\
\text { week, } 2005(\%)\end{array}$ & $\begin{array}{l}\text { Alcohol } \\
\text { consumption, } \\
\text { /person/year } \\
2005 \text { (litres) }\end{array}$ \\
\hline \multicolumn{2}{|c|}{ Germany 2003} & 33.9 & 182 & 36.5 & 26 & 11.7 \\
\hline UK & 2008 & 21.0 & 218 & 37.7 & 51 & 11.5 \\
\hline Finland & 2008 & 20.4 & 172 & 36.0 & 34 & 10.0 \\
\hline France & 2003 & 25.4 & 214 & 41.8 & 52 & 13.2 \\
\hline Spain & 2003 & 28.1 & 243 & 42.0 & 60 & 10.0 \\
\hline Greece & 2000 & 37.6 & 404 & 36.7 & 27 & 9.2 \\
\hline Estonia & 2008 & 26.2 & 174 & 25.4 & 26 & 16.2 \\
\hline Hungary & 2003 & 30.4 & 195 & 39.2 & 34 & 12.5 \\
\hline Latvia & 2008 & 27.9 & 168 & 35.9 & 29 & 10.2 \\
\hline Lithuania & 2008 & 24.2 & 187 & 27.2 & 29 & 12.5 \\
\hline Romania & 2008 & 20.2 & 209 & 27.9 & 37 & 10.5 \\
\hline Turkey & 2008 & 27.4 & 333 & 27.1 & 50 & 1.3 \\
\hline Bulgaria & 2001 & 32.7 & 132 & 31.0 & 33 & 11.0 \\
\hline EU & & & & & 41 & \\
\hline European & Region 2008 & 27.0 & 239 & 36.0 & & 10.7 \\
\hline Source & & $\begin{array}{c}\text { Data from } \\
\text { WHO/Europe } \\
\text { database (26). }\end{array}$ & $\begin{array}{c}\text { Data from } \\
\text { WHO/Europe } \\
\text { database (26). }\end{array}$ & $\begin{array}{c}\text { Data from } \\
\text { WHO/Europe } \\
\text { database (26). }\end{array}$ & $\begin{array}{l}\text { Data from British } \\
\text { Heart Foundation } \\
\text { Statistics (10). }\end{array}$ & $\begin{array}{c}\text { Data from } \\
\text { WHO/Europe } \\
\text { database (26). }\end{array}$ \\
\hline
\end{tabular}


$66,67,68,69,70,71)$. "Table 6" shows the results of comparisons of two main strategies (medical therapy versus revascularization) and two revascularization techniques including $\mathrm{PCl}$ and $C A B G$. In summary, angina relief in short term with both revascularization techniques is superior to medical therapy, but the positive effect size is becoming less important in long term. CABG is the most effective therapy for eliminating the anginal symptoms due to providing more prompt revascularization than with $\mathrm{PCl}$. The need for additional intervention is higher in $\mathrm{PCl}$ patients than in CABG group, and the revascularization rates in $\mathrm{PCl}$ patients are comparable with the patients receiving medical therapy. Drugeluting $\mathrm{PCl}$ seems superior to bare metal stenting in reducing restenosis but not death or MI. In addition, drug-eluting stents increase late stent thrombosis, and long term dual antiplatelet treatment is required. Revascularization therapies that have more procedural complications including death are shown to be beneficial in patients with proven large area of ischemia $(>10 \%)$, uncontrolled or worsening angina despite optimal medical therapy, impaired left ventricle (LV) function, significant proximal left anterior descending (LAD) or left main coronary artery (LMCA) stenosis $(\geq 50 \%)$ and extensive multivessel disease. As the most important result pointing out function more than anatomy, revascularization with $\mathrm{PCl}$ or CABG has no significant additional effect on mortality and cardiovascular event rates ( $\mathrm{Ml}$ or stroke) when compared to optimal medical therapy (OMT) alone. So, the authors suggest that medical therapy should be the first-line strategy in stable CHD patients and revascularization can safely be deferred until anginal symptoms worsen to a point that invasive treatment is required. Naturally, the revascularization guidelines were updated to emphasize the need for an objective evidence of large area of ischemia as Class I-A recommendation for invasive treatment in stable patients $(72,73,74)$. Diagnostic strategies were also influenced by these conclusions. Noninvasive testing against and with ICA gained a very important role to select the patients who benefit from revascularization.

\section{Diagnostic Strategies}

There are a lot of diagnostic tools to investigate CHD in patients with chronic stable angina, like patient history and laboratory tests revealing the cardiac risk of the individuals, electrocardiography (ECG), chest X-ray, exercise ECG, echocardiography, coronary computed tomographic angiography (CTA), coronary artery calcium (CAC) scoring, intravascular ultrasound (IVUS), cardiac magnetic resonance imaging (MRI), stress imaging with single photon emission computed tomography (SPECT) myocardial perfusion scan (MPS) or echocardiography, and finally ICA (Only MPS will be used for SPECT MPS, because planary MPS is not in use

Table 5. Economic burden of CHD in some European countries

\begin{tabular}{|c|c|c|c|c|c|}
\hline & $\begin{array}{l}\text { (GNIPc) } \\
2009 \\
\text { (PPP\$) }\end{array}$ & $\begin{array}{l}\text { Total health } \\
\text { expenditure as } \\
\% \text { of GDP, } 2008 \text { (\%) } \\
\text { (PPP\$) }\end{array}$ & $\begin{array}{l}\text { Total health } \\
\text { expenditure } \\
\text { per capita, } 2008\end{array}$ & $\begin{array}{l}\text { Cost per capita } \\
\text { for CHD, } 2003 \\
\text { (PPP } €)\end{array}$ & $\begin{array}{c}\% \text { cost of CHD } \\
\text { of total health } \\
\text { expenditure, } 2003 \\
(\%)\end{array}$ \\
\hline Germany & 36.850 & 10.4 & 3.692 & 75 & 3,0 \\
\hline UK & 35.860 & 9.0 & 3.230 & 82 & 4.1 \\
\hline Finland & 35.280 & 8.4 & 2.979 & 49 & 2.8 \\
\hline France & 33.950 & 11.1 & 3.778 & 32 & 1.4 \\
\hline Spain & 31.490 & 8.7 & 2.791 & 26 & 1.7 \\
\hline Greece & 28.800 & 9.7 & 2.852 & 40 & 2.4 \\
\hline Estonia & 19.120 & 5.9 & 1.226 & 20 & 3.1 \\
\hline Hungary & 19.090 & 7.4 & 1.419 & 20 & 2.0 \\
\hline Latvia & 17.610 & 6.5 & 1.112 & 17 & 3.7 \\
\hline Lithuania & 17.310 & 6.2 & 1.178 & 25 & 4.4 \\
\hline Romania & 14.540 & 4.7 & 665 & - & - \\
\hline Turkey & 13.500 & 5.0 & 695 & - & - \\
\hline Bulgaria & 13.260 & 7.3 & 910 & - & - \\
\hline EU & & & & 50 & 2.6 \\
\hline European Region & & 7.6 & 1.969 & & \\
\hline \multirow[t]{2}{*}{ Source } & $\begin{array}{l}\text { Data from } \\
\text { The World Bank, } \\
\text { Last Updated on } \\
\text { April 21, } 2011(31,32) \text {. }\end{array}$ & $\begin{array}{c}\text { Data from } \\
\text { WHO/Europe } \\
\text { database (26). }\end{array}$ & $\begin{array}{c}\text { Data from } \\
\text { WHO/Europe } \\
\text { database (26). }\end{array}$ & $\begin{array}{l}\text { Data from } \\
\text { the study by } \\
\text { J. Leal et al. (25). }\end{array}$ & $\begin{array}{l}\text { Data from } \\
\text { the study by } \\
\text { J. Leal et al. (25). }\end{array}$ \\
\hline & $\begin{array}{l}\text { GNIpc: Gross National } \\
\text { Income per capita }\end{array}$ & $\begin{array}{c}\text { GDP: Gross } \\
\text { Domestic Product }\end{array}$ & $\begin{array}{l}\text { PPP\$: Purchasing } \\
\text { Power Parity Dollars }\end{array}$ & $\begin{array}{l}\text { PPP€: Purchasing } \\
\text { Power Parity Euros }\end{array}$ & \\
\hline
\end{tabular}


anymore). New hybrid devices and new multimodality noninvasive imaging techniques searching different features of the disease in different stages are announced each year, and these developments bring new discussions on management of CHD (75). Noninvasive testing in stable CHD patients is still one of the most argued issues in medicine, although the clinical management of patients is carefully outlined in the "Guidelines of American College of Cardiology (ACC)/American Heart Association (AHA)/American College of Physicians/ASIM for the Management of Patients with Chronic Stable Angina", that was first published in 1999, and updated in 2002, and "Guidelines on the management of stable angina pectoris" of European Society of Cardiology (ESC), in 2006" (76,77). These guidelines tabulate the multiple published data on diagnostic use of the tests, emphasize the evidence levels, appropriateness criteria or contraindications and establish some flow diagrams about initial clinical assessment, diagnosis and treatment. These guidelines particularly ACC/AHA guidelines designate the noninvasive tests (stress ECG, stress MPS, stress echocardiography) in a concept of "stress testing with or without imaging". Both guidelines place ICA as an invasive test at the end of the diagnostic flow diagram to be reserved particularly for the high risk patients who have severe or uncontrolled angina or an evidence of ischemia in the absence of disabling

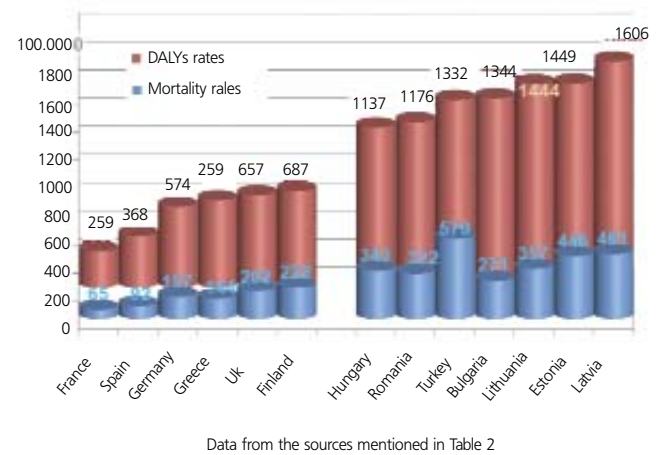

Figure 8. Age-standardized DALYs rates and mortality rates in some European countries

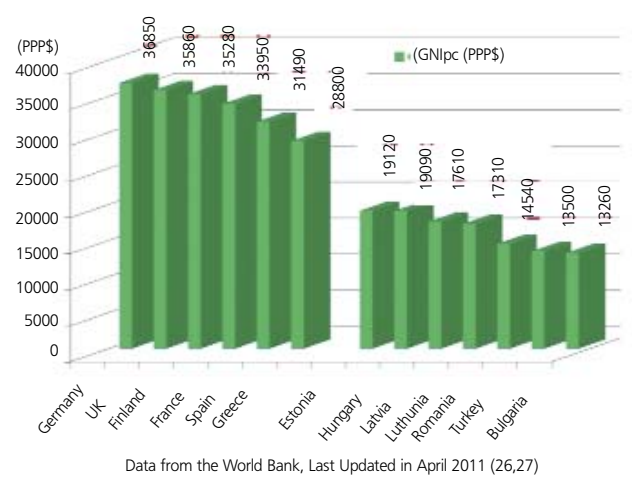

Figure 9. Gross National Income Per Capital (GNIpc) of the same European countries (PPP\$) symptoms. So, the major purpose of the use of "stress testing with or without imaging" is to indicate an objective evidence of ischemia. Because ischemia means risk in CHD patients, these tests are valuable not only for demonstrating the disease, but also for risk stratification that has long been recognized as critical in the clinical management of stable patients. "Stress testing with or without imaging" can distinguish high-risk patients who may benefit from early ICA, from non-high risk patients in whom optimal medical therapy is enough to control the disease. The patients at intermediate pretest risk are supposed to get maximum benefit from a noninvasive test, because the test makes a real change in posttest probability in this group of patients. Relatively fewer ones are supposed to be seperated as at high risk after noninvasive testing who need further investigation and/or revascularization that are costly. The annual cardiac event rate in patients who are found to be at low risk by "stress testing with or without imaging" is less than 1\% (which is similar for low risk Duke treadmill scores and normal studies of stress MPS or stress echocardiography) (78). So, the non-high risk patients will only be investigated further if their symptoms cannot be controlled with medical therapy alone. That's why ischemia searching strategy provides better prognostic outcomes with less expenditure while stenosis searching strategy causes unnecessary revascularization without any improvement in prognosis. Another potential advantage of noninvasive stress testing is the demonstration of ischemia in patients without obstructive CHD who do not need revascularization, although they have relatively poor prognosis (78).

In the routine practice, clinical presentation, severity of angina, pretest probability, expected clinical utility, economic availability, contraindications and patient preferences are considered for choosing the optimal diagnostic test or strategy. Hovewer, the appropriate use of the tests are established in the guidelines basically according to the existence of the symptoms and pretest probability. Diagnostic strategies for ACSs are beyond the scope of this article, and only the guidelines about symptomatic stable patients and asymptomatic adults considering "stress testing with or without imaging" will be mentioned here shortly. In asymptomatic adults (79), global risk scoring (such as the Framingham risk scoring) is recommended for cardiovascular risk assesment, but exercise ECG (that may only be considered

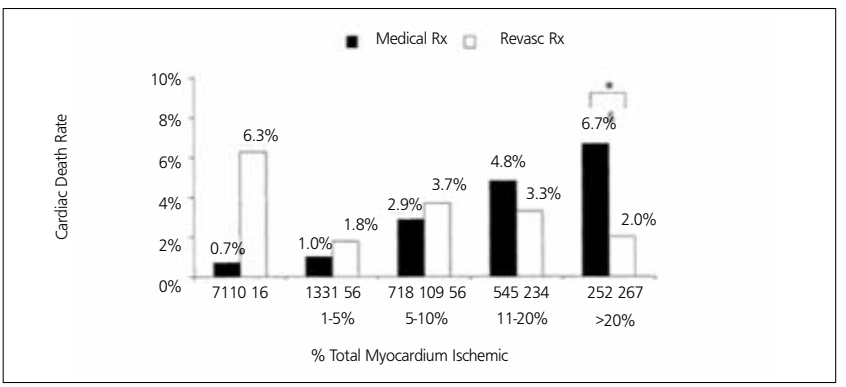

Figure 10. Observed cardiac death rates over the follow-up period in patients undergoing revascularization (Revasc Rx) vs medical therapy (Medical Rx) as a function of the amount of inducible ischemia. $(P<0.0001)$ Ref. 88 


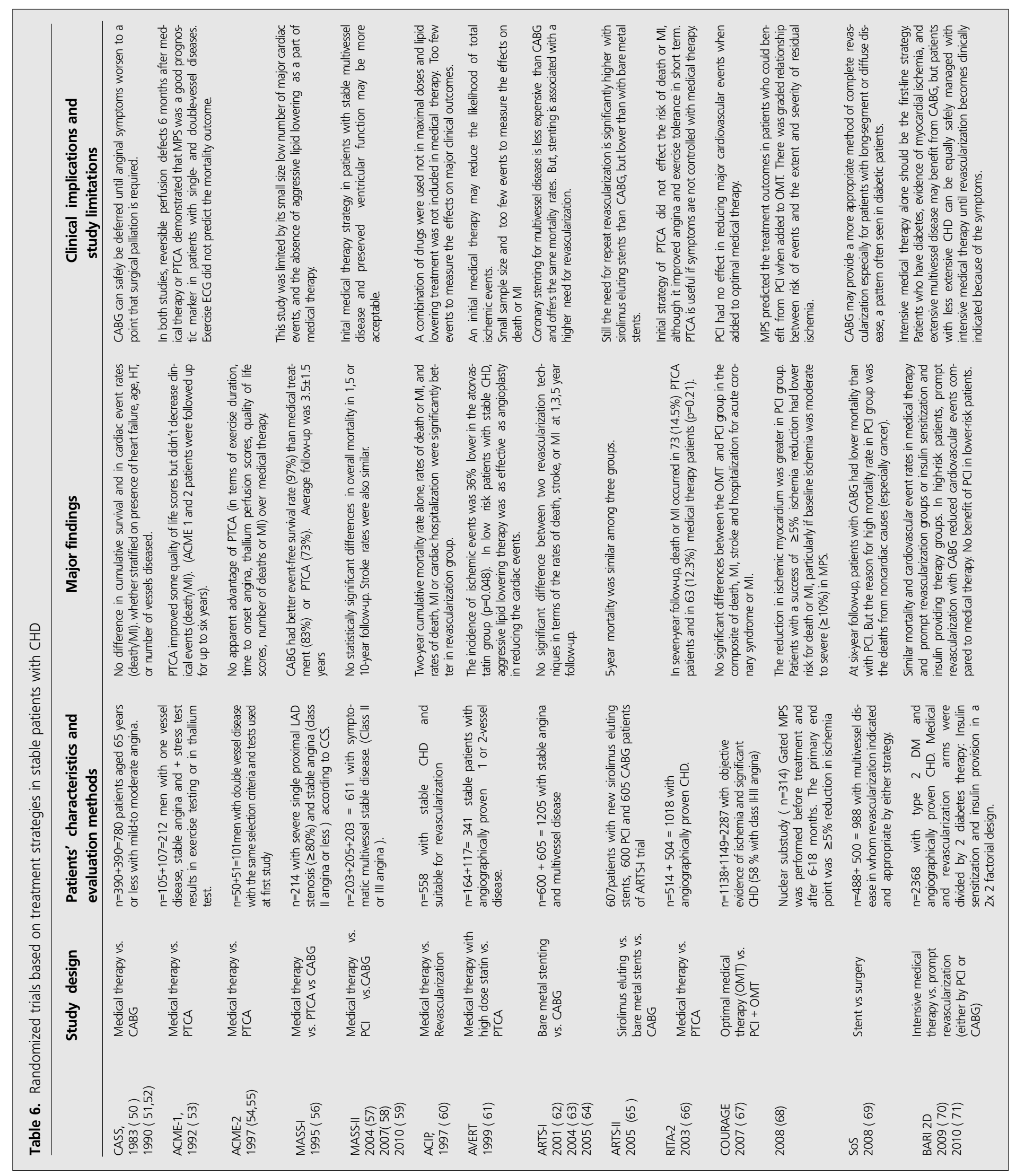


for the sedentary adults before starting a vigorous exercise program), echocardiography, stress echocardiography and stress MPS are not indicated in low and intermediate risk asymptomatic patients. Stress MPS is stated to be considered for the advanced cardiovascular risk stratification only in high risk asymptomatic patients with DM or evident family history of $\mathrm{CHD}$ or previous risk assesment testing indicates high risk of CHD such as coronary calcium (CAC) score of $\geq 400$. But, it is strongly emphasized that stress imaging tests should be reserved for the advanced cardiovascular risk stratification of the symptomatic patients. CTA is not indicated for cardiovascular risk assesment in asymptomatic patients (79).

In patients with stable angina, stress ECG without imaging is recommended for those with intermediate pre-test probability of CHD based on age, gender, and symptoms, if not unable to exercise or ECG displays nonspecific changes $(76,77)$. For risk stratification, it is indicated for the patients undergoing initial evaluation and for those with known CHD who suffer from significant deterioration in symptoms but not after recent revascularization $(76,77)$. Routine periodic testing once angina is controlled is not indicated (77). Stress testing with imaging (exercise or pharmacological stress echocardiography/MPS), as opposed to exercise ECG, is recommended for the following conditions: 1) complete left bundle-branch block, electronically paced ventricular rhythm, pre-excitation (Wolff-Parkinson-White) syndrome, and other similar ECG conduction abnormalities; 2) patients who have more than $1 \mathrm{~mm}$ of ST-segment depression at rest, including those with left ventricular hypertrophy or taking drugs such as digitalis; 3) patients who are unable to exercise to a level high enough to give meaningful results on routine stress ECG who should be considered for pharmacologic stress imaging tests; and 4) patients with angina who have undergone prior revascularization, in whom localization of ischemia, establishing the functional significance of lesions, and demonstrating myocardial viability are important considerations (76). Stress imaging methods are recommended for risk stratification to identify the extent, severity, and location of ischemia, to assess the functional significance of coronary lesions in planning $\mathrm{PCl}$, to indicate the functional severity of intermediate lesions found in ICA, and to predict the outcome of the treatment strategies $(76,77,80)$. MPS is also indicated in symptomatic patients with known $\mathrm{CHD}(76,77)$. Assessment of response to therapy is another goal of using MPS (80). Table 7, 8 and 9 summarize the characteristics of the tests used for showing stress induced ischemia.

Cardiac MRI, IVUS, SPECT/CT, PET/CT, PET/MRI and some other techniques are investigated for the diagnosis of $\mathrm{CHD}$, but CTA is the most promising new diagnostic tool currently discussed as an anatomic but noninvasive test against the

Table 7. Advantages and disadvantages of Stress ECG in comparison to stress imaging methods $(76,81,82)$

\section{Advantages of stress ECG}

1. The cheapest and widely available test

2. Stress-induced ischemia is well documented particularly with Duke's treadmil scorring

3. Predicts prognosis particularly with Duke's treadmil scorring

4. Very informative if maximal exercise

capacity is reached, especially in young adults.

\section{Disadvantages of stress ECG}

1. The lowest accuracy

2. Can not indicate ischemia region and severity

3. Nonconclusive when insufficient exercise capacity particularly in older people and women.

4. Nonconclusive when there are ECG conduction abnormalities, LV hypertrophy and digitalis use.

5. Generally not supervised by a trained physician or cardiologists in the clinics.

6. Not cost-effective for overall patient care when compared to stress imaging as a first-line strategy.

Table 8. Comparative advantages of stress echocardiography and stress MPS in diagnosis of CHD

\section{Advantages of Stress Echo}

\section{Higher specificity}

2. Versatility-more extensive evaluation of cardiac anatomy and function.

3. Greater convenience/efficacy/availability particularly with dobutamin stress, but not with exercise stress.

4. Lower cost for test itself

5. No ionizing radiation

\section{Advantages of stress MPS}

1. Higher sensitivity-especially for single vessel coronary disease involving the left circumflex

2. Objective display of perfusion and function.

3. Higher technical success rate with all exercise, dobutamin and vasodilator stress

4. Better accuracy in evaluating possible ischemia when multiple resting LV wall motion abnormalities are present 5. More extensive published database, especially in evaluation of prognosis. 
"stress testing with or without imaging". It is particularly proposed for the patients with more atypical symptoms and a lower likelihood of CHD (85). Some studies suggest that CTA may potentially reduce both the time spent and overall cost in the lower risk patients who otherwise would have been subjected to more expensive and possibly less accurate testing strategies (85). Shaw and Narula propose CTA for lower range of intermediate risk $(<50 \%)$ patients as a first line noninvasive imaging test while they suggest MPS or PET for upper range of intermediate (50-85\%) and high risk (>85\%) patients based on consideration of added clinical value and economic outcomes(86). In a recent study with referral and some verification biases, Weustink et al. propose CTA for the intermediate risk patients (87). But, Gibbons strongly

Table 9. Summary of noninvasive test characteristics used in the diagnosis of stable angina (77)

Sensitiivity (\%) Specificity (\%)

\begin{tabular}{lcc}
\hline Exercise ECG & 68 & 77 \\
Exercise echo & $80-85$ & $84-86$ \\
Exercise MPS & $85-90$ & $70-75$ \\
Dobutamin stress echo & $40-100$ & $62-100$ \\
Vasodilator stress echo & $56-92$ & $87-100$ \\
Vasodilator stress MPS & $83-94$ & $64-90$ \\
\hline
\end{tabular}

Reproduced from Ref. 77 emphasizes that CTA has a fairly limited evidence base while "stess testing with or without imaging" has robust evidences from the randomized studies with huge populations (78). He also emphasizes the relationship between the current healthcare crisis in US and the usage of newly developing tests outside the guidelines without sufficient evidence (78). Although CTA is proved to detect coronary stenosis accurately, the clinical utility of the proved stenosis remains unclear, because CTA is a poor predictor of inducible ischemia not only in patients with $<50 \%$ narrowing in a coronary vessel but also with $\geq 50 \%$ coronary stenosis. Furthermore, Gibbons points out that an anatomic approach with CTA may possibly reduce the life style and risk factor modifications in patients who are found to be normal or near-normal in the test. On the other hand, Min and Shaw, as it is written in a letter to editor for the same article, believe that "identification of individuals with less severe forms of atherosclerosis permits more aggressive risk factor modification and medical treatment at an earlier stage" (78). But, no data is available to support any of these ideas in terms of clinical utility and economic consequences. Table 10 shows the advantages and disadvantages of CTA as a cardiac noninvasive test.

Anatomic or functional approaches, in other terms, stenosis or ischemia searching strategies are in competition for the diagnosis of $\mathrm{CHD}$, although in fact they are complementary for a more precise diagnosis in some situations. ICA as a gold standart in the evaluation of stenosis provides direct radiographic visualization of the structural features of the coronary artery lumen (85). MPS as a

Table 10. Advantages and disadvantages of CTA used in the diagnosis of CHD (78,85-87)

\section{Advantages of CTA}

1. Evaluates the coronary anatomy and LV function.

2. In most of the studies, CTA results correlate well with

ICA in showing the atherosclerotic burden.

3. Negative results rule out significant obstructive CHD confidently.

4. Indicates plaque characteristics:

* Ischemia, mostly with calcified or mixed plaques.

* ACS, more with noncalcified vulnerable plaques.

5. The usefulness of CTA is discussed particularly for low-intermediate patients with more atypical symptoms.

6. CTA can be used to rule out severe in-stent restenosis in patients with $C A B G$

\section{Disadvantages of CTA}

1. Cannot detect ischemia and the clinical importance of the existing stenosis accurately.

2. In the studies, the population selected for CTA is generally chosen from the population selected for ICA, although CTA is not used in such population routinely.

3. Positive results are more variable, and potentially overestimate disease severity.

4. Early detection of noncalcified possibly vulnerable plaques has no role in current practice yet because of insufficient data to assess its clinical utility.

5. Not accepted in guidelines yet because of insufficient data from randomized controlled trials and some referral and verification biases of the existing studies.

6. Less accurate information about the native arteries distal to the bypasses and the ungrafted arteries. Metal artifact associated with PTCA stents is another difficulty.

7. Exposing patients to ionizing radiation and iodinated contrast agents

8. Low quality of studies in patients with irregular heart rates (e.g., atrial fibrillation), obesity and inability to comply with instructions for breath holding,

9. Contraindicated in patients with iodine allergy or renal failure. 
functional test is proved to be the most important tool to indicate ischemia, its region and severity and to predict prognosis which is more practical than stress echocardiography in outpatient clinics $(76,78,86)$. To compare these two anatomic and functional approaches and express the picture particularly in terms of nuclear medicine, we can make a simple simile for the heart as a cultivated field and coronary vessels as the pipes carrying water. To evaluate the

Table 11. Cost-effectiveness trials based on the diagnostic strategies in stable patients with CHD

\begin{tabular}{|c|c|c|c|c|}
\hline & Study design & $\begin{array}{l}\text { Patient } \\
\text { population }\end{array}$ & Major findings & $\begin{array}{l}\text { Clinical implications and } \\
\text { study limitations }\end{array}$ \\
\hline $\begin{array}{l}\text { The } \\
\text { EMPIRE study, } \\
1999(82)\end{array}$ & 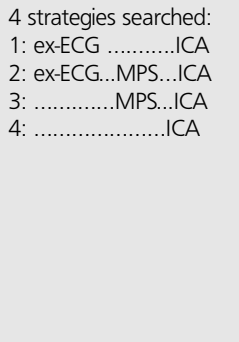 & $\begin{array}{l}n=396(8 \times 50) \\
\text { ( } 8 \text { centers: } 4 \text { MPS } \\
\text { users and } 4 \text { non-users } \\
\text { from EU) }\end{array}$ & $\begin{array}{l}\text { *Diagnostic power for strategies: } \\
\text { When CHD was present: } \\
\text { 1: } 85 \%, 2: 82 \%, 3: 97 \%, 4: 100 \% \\
\text { Users: } 93 \% \text {, Non-users: } 88 \% \\
\text { When CHD was absent : } \\
\text { 1: } 26 \%, 2: 22 \%, 3: 16 \%, 4: 0 \% \\
\text { Users: } 21 \%, \text { Non-users: } 20 \% \\
\text { *Prognostic power was higher ( } P<0.0001) \text { and } \\
\text { normal ICA rate was lower }(p=0.07) \text { in MPS using } \\
\text { centers. }\end{array}$ & $\begin{array}{l}{ }^{*} \text { Mean diagnostic costs per patient: strategy } 2<3<1< \\
4 \mathrm{P}<0.0001) \\
{ }^{*} \text { Total 2-year costs with follow-up: } \\
\text { When CHD was present: } \\
\text { strategy } 3<2<1<4(\mathrm{P}<0.05) \\
\text { When CHD was absent: } \\
\text { strategy } 2<3<1<4(\mathrm{P}<0.0001) \\
{ }^{*} \text { Diagnostic strategies with MPS are cheaper than with- } \\
\text { out MPS, for both diagnosis and overall 2-year costs. Two- } \\
\text { year outcomes are the same. }\end{array}$ \\
\hline $\begin{array}{l}\text { The } \\
\text { END trial } \\
1999 \text { (97) } \\
1999 \text { (98) } \\
\text { only in women } \\
\text { (Similar resuls } \\
\text { were found in } \\
4638 \text { women) }\end{array}$ & $\begin{array}{l}2 \text { strategies serached } \\
\text { 1: Initial direct ICA: } \\
\text { 2:Initial stress MPS and } \\
\text { then selective ICA }\end{array}$ & $\begin{array}{l}n=11,372 \\
(5,423+5,826) \\
\text { Patient properties are } \\
\text { similar in two groups. }\end{array}$ & $\begin{array}{l}\text { *Revascularization rate was } 73 \% \text { in patients who } \\
\text { undergone ICA directly. } \\
{ }^{*} \text { Revascularization rate was } 14.6 \% \text { in patients who } \\
\text { undergone MPS first end then selective ICA. ( MPS } \\
(+) \text { rate was } 34 \% \text { and } 43 \% \text { of the patients with } \\
\text { positive test result undergone revascularization). }\end{array}$ & $\begin{array}{l}{ }^{*} \text { Composite cost of care was } 30-41 \% \text { lower in patients } \\
\text { undergoing initial MPS (lower in all pretest risk groups) } \\
{ }^{*} \text { Cardiac event rates were similar in low, intermediate } \\
\text { and high risk patients in two groups. The risk of cardiac } \\
\text { death in patients with normal MPS was exceedingly low } \\
\text { in 3-year follow-up. }\end{array}$ \\
\hline $\begin{array}{l}\text { A systematic } \\
\text { review } \\
2004 \text { (99) }\end{array}$ & $\begin{array}{l}4 \text { decision tree models: } \\
\text { 1.ex-ECG........ ICA } \\
2 . \text { ex-ECG...MPS...ICA } \\
3: \ldots \ldots \ldots \ldots . . \text { MPS...ICA } \\
4: \ldots \ldots \ldots \ldots \ldots \ldots \ldots . . . \text { ICA } \\
\text { (if the previous test is } \\
+ \text { then peform the } \\
\text { next test). }\end{array}$ & $\begin{array}{l}21 \text { diagnostic and } \\
46 \text { prognostic studies } \\
\text { were evaluated. }\end{array}$ & $\begin{array}{l}\text { *MPS provided a better diagnostic performance } \\
\text { than ex-ECG. } \\
\text { *MPS provided valuable independent and incremen- } \\
\text { tal prognostic information to that provided by stress } \\
\text { ECG and/or ICA. }\end{array}$ & $\begin{array}{l}\text { *Comparison of the overall costs and QALY's : } \\
\text { strategy } 2<3<1<4 \text { The same for either in cost (f) or } \\
\text { in QALY's. } \\
{ }^{*} \text { This systematic review indicated that strategies involving } \\
\text { MPS were likely either to be dominant or to produce } \\
\text { more QALYs at an acceptable cost. }\end{array}$ \\
\hline $\begin{array}{l}\text { A summary of } \\
\text { the literature } \\
\text { Costeffectivene } \\
\text { ss of MPS } \\
2005 \text { (100) }\end{array}$ & $\begin{array}{l}\text { A summary of the cur- } \\
\text { rently available litera- } \\
\text { ture }\end{array}$ & $\begin{array}{l}1993 \text { to } 2004 \text {, } \\
22 \text { studies about cost- } \\
\text { effectiveness of nonin- } \\
\text { vasive testing includ- } \\
\text { ing MPS were } \\
\text { assessed. }\end{array}$ & $\begin{array}{l}\text { *Cost per QALY for ex-ECG was above the accept- } \\
\text { ed treshold. } \\
\text { *7 out of } 10 \text { studies comparing MPS with stress } \\
\text { echo favored MPS testing approach. } \\
{ }^{*} \text { In intermediate risk petients, MPS as a first line } \\
\text { strategy is more costeffective when compared to } \\
\text { initial ICA strategy. } \\
\text { *The results consistently note significant cost savings } \\
\text { when MPS is used as a gatekeeper by limiting } \\
\text { angiography to only patients with } \\
\text { provokable ischemia. }\end{array}$ & $\begin{array}{l}\text { *In summary, evidence is convincing that, for the interme- } \\
\text { diate-risk patients, initial investigation with MPS } \\
\text { is a cost-efficient approach. In special populations includ- } \\
\text { ing emergency-department patients, diabetic patients, } \\
\text { and women, there is additional data indicating the cost- } \\
\text { effectiveness of MPS. } \\
\text { *For low-risk patients, a costeffective strategy appears to } \\
\text { be stress ECG, } \\
\text { with the selective use of MPS. } \\
\text { *linitial MPS is indicated even in stable patients with a } \\
\text { high probability of CHD, because it provides additional } \\
\text { data to help direct the most effective use of revascular- } \\
\text { ization. }\end{array}$ \\
\hline $\begin{array}{l}\text { The } \\
\text { CECaT trial } \\
2007(101)\end{array}$ & $\begin{array}{l}4 \text { decision tree models: } \\
\text { 1.ICA first 2.MPS first } \\
\text { 3: MRI first 4: Stress } \\
\text { echo first. The patients } \\
\text { undergone ICA when } \\
\text { needed. } \\
\text { In } 83 \% \text { of MPS, } 89 \% \\
\text { of MRI and } 84 \% \text { of } \\
\text { stress echo patients, } \\
\text { positive tests were } \\
\text { confirmed by ICA. } \\
\text { Negative tests were } \\
\text { followed by positive } \\
\text { ICA in } 31 \% \text { of MPS, } \\
52 \% \text { of MRI and } 48 \% \\
\text { of stress echo patients. }\end{array}$ & $\begin{array}{l}\mathrm{n}=898 \text { patients with } \\
\text { suspected or known } \\
\mathrm{CHD} \text {, if } \\
\text { ex-ECG results do not } \\
\text { require urgent ICA. } \\
\text { Patients were ran- } \\
\text { domised to } \\
\text { ICA }(n=222) \text {, MPS } \\
(n=224), M R I(n=226) \\
\text { or } \\
\text { stress echo }(n=226) \text {. } \\
\text { Similar groups at base- } \\
\text { line. }\end{array}$ & $\begin{array}{l}\text { MRI had the largest number of test failures and had } \\
\text { the least practical use in screening patients with sus- } \\
\text { pected CHD, although it had similar outcomes to } \\
\text { stress echo. Stress echo patients had a } 10 \% \text { test fail- } \\
\text { ure rate, significantly shorter total exercise time and } \\
\text { time to angina at } 6 \text { months post-treatment, and a } \\
\text { greater number of adverse events leading to signifi- } \\
\text { cantly higher costs. It may be best to reserve this test } \\
\text { for those who have a contraindication to MPS and } \\
\text { are unable or unwilling to have MRI. }\end{array}$ & $\begin{array}{l}\text { Between } 20 \text { and } 25 \% \text { of patients can avoid invasive test- } \\
\text { ing using functional testing as a gateway to ICA without } \\
\text { substantial effects on outcomes. The MPS strategy was } \\
\text { as useful as ICA } \\
\text { in identifying patients who should undergo revasculariza- } \\
\text { tion. The additional cost for MPS strategy was not signif- } \\
\text { icant. } \\
\text { In this study, MPS had the best outcomes, reflecting the } \\
\text { greater experience of using this technique, although the } \\
\text { differences between the tests were minor. }\end{array}$ \\
\hline
\end{tabular}


irrigation condition in a field, one tries to control each of the pipes and if something is found narrowing or blocking inside, that pipe will be opened if possible on site. Another option is looking at the field from above. Brown or black areas are interpreted as the lack of irrigation, yellow areas as poor perfusion and the green areas as normal situation. First option like ICA evaluates the pipes but is blind to the field and the second option like MPS evaluates the irrigation condition in the field but is blind to the pipes. The heart is so distinctive that reporting a coronary artery as completely open or blocked does not say anything about the perfusion in the field in some situations, because the heart has some renewing mechanisms itself by angiogenesis that result in new and rich collateral vessels carrying blood and oxygen to the end point and prevent the heart from ischemia even if a main vessel is completely blocked. On the other hand, CHD symptoms may appear when coronary anatomy is completely normal as it is mentioned before. So, if we want to understand what is happening in the field and predict response to therapy, we have to observe the perfusion and function of the myocardium directly or prove ischemia by the way of other stress testing methods indirectly. MPS does not measure the degree of coronary stenosis but detects the results of atherosclerotic disease as the abnormalities in perfusion and function of the myocardium related to the severity of stenosis. Collateral flow and underlying endothelial dysfunction are also important parameters effecting MPS results, which make us understand the whole picture about prognosis. In the future, an imaging tool uniting these anatomic and functional points of view or some hybrid systems supplying anatomic, functional and/or perfusion data at the same time may be developed, but currently, these data are basically obtained from different imaging methods. So, MPS is an indispensable test yet for not only determining the perfusion with function but also for its proved strength to predict prognosis particularly in intermediate and high risk patients.

All tests have some advantages and disadvantages, but the tests, in relation to treatment strategies, are expected to answer the question about what will happen to the patient. Will the test results change the way of therapy (surgical or medical?) or will the patient benefit from the therapy which the test results point out. The underlying burden of atherosclerotic disease is often more severe than the burden of myocardial ischemia (86) but mostly, the severity of myocardial ischemia predicts prognosis and response to revascularization $(68,86)$. So, risk determination in most patients is more valuable than defining the burden of atherosclerotic disease in deciding treatment strategy. MPS has a unique role in risk stratification and patient selection for revascularization by defining the extent and severity of ischemic myocardium. In a study by Hachamovitch (88), cardiac death rate was found to be directly associated with the relevant treatment strategy guided by the the severity of ischemia with MPS. Cardiac death rate decreases when the patients with moderate to severe myocardial ischemia undergo revascularization and the medical therapy is chosen in the absence of ischemia. Mortality increases if the patients with no myocardial ischemia undergo revascularization or those with moderate $(5-10 \%)$ to severe $(>10 \%)$ myocardial ischemia are medically treated (Figure 10). COURAGE nuclear substudy (68), a more recent randomized multicenter trial searching the value of MPS ischemia to guide therapeutic decision making, concluded that the addition of $\mathrm{PCl}$ to OMT resulted in more effective reduction of ischemia than OMT alone and complete normalization of MPS was more common in $\mathrm{PCl}+\mathrm{OMT}$ group. Reductions in ischemia were associated with improvements in angina frequency and stability and $\geq 5 \%$ ischemia reduction was found related to considerably decreased cardiac event rate (68). Thus, a failure in reducing a patient's ischemic burden signifying a high-risk status warranted intensification of OMT and consideration of repeat angiography and/or revascularization (86). The magnitude of residual ischemia in follow-up MPS was proportional to the risk of cardiac events after either OMT or revascularization. More severe residual ischemia was associated with higher death or MI rates $(68,86)$. So, despite its accuracy problems to indicate the atherosclerotic burden, MPS is the most powerfull independent predictor of prognosis $(53,54,68,82,89,90)$. Anatomic approaches can detect the burden of atherosclerotic disease, but ischemia searching test is needed to see the light in the tunnel when considering the treatment strategies particularly in intermediate risk patients. CAC scoring $(91,92,93)$ and CTA may be added to MPS $(93,94,95)$ for a more complete evaluation in the conditions of unclear positive test results. SPECT/CT, PET/CT (96) or PET/MRI systems may be improved in the future to obtain the data of all aspects of coronary morphology with function for routine use.

Resource expenditure gains importance in noninvasive imaging of $\mathrm{CHD}$, because of the various newly developed diagnostic techniques. Cost-effectiveness of the tests was searched comparatively in randomized and observational studies (Table 11). The diagnostic strategy of direct ICA in stable patients results in higher rates of coronary revascularization without improvements in clinical outcomes $(82,86,97,98,99,100)$. That's why the seeking for a gatekeeper to select the patients who do not need to undergo ICA is put on the agenda. In most of the studies, MPS as a first line strategy is found to be highly cost-effective with its power in risk stratification when compared to ICA first strategy $(82,86,97-102)$. Negative MPS results favorably exclude significant CHD and patients with normal MPS have $<1 \%$ cardiac event rate in 2-3 years. Only $1 \%$ of the patients with normal MPS undergo downstream ICA (100). In an analysis based on the summary of the literature (100), 3 studies note that a strategy of "direct ICA" resulted in revascularization rates of $16 \%$ to $44 \%$ compared with the rates of $6 \%$ to $20 \%$ for "MPS first and then selective ICA" strategy without a negative impact on outcomes. In the END trial with 11,372 patients (97), revascularization rate was $73 \%$ in direct ICA strategy $(3,958 / 5,423$ patients) while it was $14.6 \%$ in "MPS first and then selective ICA" strategy $(851 / 5,826$ patients). In the second group, positive MPS rate was $34 \%$. In other words, $2 / 3$ of the patients were found to 
have normal MPS and excluded from additional expensive diagnostic evaluation. Diagnostic and 3-year follow-up costs were evidently high in patients undergoing direct ICA, because this strategy leaded more revascularization unrelated to the rate of $\mathrm{CHD}$ in the population. Composite cost of care was $30-41 \%$ lower in patients undergoing initial MPS. More ICA does not decrease the death or MI rates as it is believed and performed in the routine practice, because aggressive treatment may not always be considered appropriate, or result in improved cardiac outcomes. The EMPIRE study (82), a randomized multicenter study from Europe, proved that MPS using strategies were more costeffective than strategies without using MPS, even than the initial stress ECG strategy. In fact, stress ECG without an imaging modality is the cheapest and widely available tool for evaluating the stress induced ischemia in patients with intermediate pretest probability, but its accuracy is low, that's why the overall cost of first-line strategy with this test is found to be higher than with MPS. A lower cost of a test alone does not necessarily result in a lower overall cost of patient care, because the cost of additional testing and intervention may be higher when the first-line test is less accurate $(76,107)$.

Stress echocardiography is one of the cost-effective methods in competition with MPS in intermediate risk patients, but in a summary of the literature about costeffectiveness of MPS revealed that 7 of 10 studies favored MPS for its technical advantages and well established pathway to ICA with comparable cost-effectiveness in long term (100). In a study by Shaw et al., stress echocardiography was found preferable in patients with low-to-intermediate pretest risk, while MPS was favorable in patients with intermediate-to-high pretest risk or known CHD. When compared to stress echocardiography, MPS was associated with early referral to angiography and revascularization $(p<0.0001)$, and this resulted in a 3-year improvement in life expectancy (103).

In studies investigating the cost-effectiveness of CTA, for patients with suspected $C H D$, the high negative predictive value of CTA resulted in more cost savings when compared to MPS, and 9-month clinical outcomes were similar with these two modalities. But for patients with known CHD, cost of care was much higher with CTA, because of repeated ICA after the test $(86,104,105)$. An anatomic diagnostic approach with CTA results in lower revascularization rates than with ICA, but, yet its percentage of $\mathrm{PCl}$ or $\mathrm{CABG}$ is 2-fold higher than with MPS. It appears that anatomic approaches, either invasive or noninvasive, result in higher rates of revascularization (86).

So MPS, as an outstanding noninvasive cardiac test providing a cost-effective solution besides its diagnostic and prognostic power, is accepted in some extensive analyses as a "gatekeeper" before ICA, particularly in intermediate and high risk patients and in patients with known CHD $(82,97,100,102,106)$. In symptomatic patients with low pretest probability, MPS is indicated after equivocal or positive ECG stress test results or to clarify the significance of stenosis found in CTA when the results of these tests are not indicative for leading directly to ICA $(76,86,107)$.
It may be thought that the results of the studies investigating the cost-effectiveness of noninvasive testing in US and EU may not reflect the economic outcomes in Turkey, because the prices for the tests are lower in our country. Some studies based on the diagnostic strategies should be planned for realizing the economic models in Turkey, but the comparative analysis based on PPP\$ is expected to give similar results, because all the tests and the other services are cheaper in our country and furthermore the cost of a test alone does not have a great value in cost-effectiveness analysis of overall patient care.

As a provider and inspector of direct health care expenditure on behalf of the goverment, SGK, Turkish national social security establisment, performs package pricing for ICA. ICA and some PCl applications are evaluated in a package price. It seems logical at first glance, but is criticized in a study by YIlmaz MB et al. and they concluded that a rational cost-assessment system should take risk factors into consideration (108). They warn about the potential ethical problems particularly when the risky and complicated patients are the subjects. As it is extensively discussed here in this article, taking risk factors into consideration is much more important in noninvasive testing. Keeping MPS outside the package pricing is reasonable, because, in a given amount of money, a cheaper probably ineffective diagnostic test chosen for inappropriate population may lead to a more expensive overall patient care with an unnecessary invasive treatment. Another nonethical situation may appear when not using a noninvasive test under the pressure of economic limitations. The results of performing direct ICA are mentioned above in detail. In a study with 499 patients who underwent ICA in Israel, $58 \%$ of the procedures were found inappropriate due to error in management before performing ICA (109). Therefore, the test should be chosen in connection with the possible treatment strategies considering its power of risk determination. The pretest risk of the patients, the abilities of the individuals and their general health conditions should also be considered. Laupacis and colleagues have proposed guidelines for optimal integration of clinical and economic outcomes (110). Gibbons supports the guidelines as a solution for health care crisis in US until reaching a consensus on a new test or technique with reasonable evidences (78). Within the guidelines, some algorithms may be accepted for decision making. In Turkey as a middle-low income country, we'd better obey the guidelines for a sustainable health care system with little exceptions of some unsuitable conditions of the patients. MPS with robust evidences from the literature may provide not a perfect but an optimal solution when it is approved as a "gatekeeper in an algorithm before ICA. "MPS first and then ICA" strategy may provide better clinical and economic outcomes than ongoing situation in Turkey as well. Significant cost savings may be obtained without effecting clinical outcomes $(97,100)$. There are currently sufficient number of nuclear medicine physicians and centers to realize this in our country (111).

Registration may guide the health policy makers to see the whole picture, but as it is emphasized in EUROASPIRE III study 
(112) recording patient data is still a problem in Turkey. Another problem is reaching the existing data. Disease specific data should be collected and shared with the professionals to foresee the clinical and economic consequences and plan the future.

As the MPS interpretors, nuclear medicine physicians should plan some studies not only focusing on the technical aspects of MPS but also its clinical usage, availability, clinical and economic outcomes, decision tree models, determining the indication, expectations from the test, clinician's perspective, patient's perspective, dealing with some spesific patients (women, diabetics, emergency department patients), improving and standardizing the technique, minimizing radiation exposure, standard reporting, etc.. All items need to be evaluated carefully. A recent study with striking results by Yapıcı O. indicates the need for clarifying the clinical usage of MPS in patients with different pretest probabilities (111). Some others should be expected.

\section{Primary Prevention vs Secondary Prevention}

Between 1981 and 2000, age specific CHD mortality in England and Wales fell by $62 \%$ in men and $45 \%$ in women aged $25-84$. Approximately $58 \%$ of the fall in mortality was attributable to risk factor reductions -mainly smoking, cholesterol, and blood pressure (113). A study by Unal B et al. revealed that primary prevention had a fourfold greater impact than secondary prevention (113). Although the Turkish "prevention and control program for cardiovascular diseases" was first declared in $2007(13,14)$ and the Turkish arm of EUROASPIRE study in 2010 concluded that the efforts for CVD prevention fall short of the targets similar to Europe (112), the efforts of struggling with smoking, obesity and HT should be maintained intensely. Such efforts are expected to reach their goal in long term. Thus, the prevalence of $\mathrm{CHD}$ will increase in the community in relation to increase in life in the future, and probably a greater attention to the issue will be needed.

\section{Abbreviations and Acronyms}

ACIP: Asymptomatic Cardiac Ischemia Pilot study

ACME: Angioplasty Compared to Medicine

ARTS: Arterial Revascularization Therapies Study

AVERT: Atorvastatin Versus Revascularization Treatment

BARI 2D: Type 2 Diabetes and Coronary Artery Disease

CABG: Coronary Artery By-pass Grafting

CASS: Coronary Artery Surgery Study

CECaT: Cost-Effectiveness of functional Cardiac Testing.

CCS: Canadian Cardiovascular Society

COURAGE: Clinical Outcomes Utilizing Revascularization and Aggressive Drug Evaluation.

DM: Diabetes Mellitus

EMPIRE: Economics of Myocardial Perfusion Imaging in Europe.

END: Economics of Noninvasive Diagnosis

HDL-C: High density lipoprotein cholesterol

HT: Hypertension
LDL-C: Low-density lipoprotein cholesterol

MASS: Medicine, Angioplasty or Surgery Study

MPS: Single photon emission computed tomography, myocardial perfusion scan

PPP: Purchasing Power Parity. Exchange rate equalises the purchasing power of different currencies often used to compare the standards of living between countries.

PCl: Percutaneous coronary intervention

PTCA: Percutaneous transluminal coronary angioplasty

QALY: Quality Adjusted Life Year.

RITA-2: Second Randomized Intervention Treatment of Angina

SoS: Surgery or Stent

TEKHARF: Turkish Adult Risk Factor

\section{References}

1. Ünüvar N, Mollahaliloğlu S, Yardım N; Refik Saydam Hygiene Center, School of Public Health, on behalf of The Ministry of Health of Turkey (MoH). Turkey Burden of Disease Study 2004. 1th ed. MoH publication no: 701. Ankara, 2007:4-8

2. Klein W. Cardiovascular Disease At The Turn Of The Millennium: Focus on Europe. Eur Heart J 2001;3 (Suppl):2-6.

3. Sans $S$, Kesteloot $H$, Kromhout $D$; on behalf of the Task Force of European Society of Cardiology (ESC) on Cardiovascular Mortality and Morbidity Statistics in Europe. The burden of cardiovascular diseases mortality in European Heart Journal 1997;18:1231-1248.

4. Murray CJL, Lopez AD. Alternative projections of mortality and disability by cause 1990-2020 : Global Burden of Disease Study. Lancet 1997;349:1498-1504.

5. Murray CJL, Lopez AD. Global mortality, disability, and the contribution of risk factors: Global Burden of Disease Study. Lancet 1997;349:1436-1442.

6. Mathers $C D$, Lopez $A D$, Murray $C J L$. The Burden of Disease and Mortality by Condition: Data, Methods, and Results for 2001. In: Lopez AD, Mathers CD, Ezzati M, Jamison DT, Murray CJL (eds). Global Burden of Disease and Risk Factors. A copublication of The World Bank and Oxford University Press 2006;45-234.

7. Lopez AD, Mathers CD, Ezzati M, Jamison DT, Murray CJ. Global and regional burden of disease and risk factors, 2001: systematic analysis of population health data. Lancet 2006;367:1747-1757.

8. WHO. The Global Burden of Disease: 2004 Update. Switzerland, WHO Press 2008,1-49.

9. Scholte op Reimer WJM, Gitt AK, Boersma E, Simoons ML; on behalf of European Society of Cardiology. Cardiovascular Diseases in Europe, Euro Heart Survey-2006. Sophia Antipolis 2006;1-20.

10. Allender S, Peto V, Scarborough P, Boxer A, Rayner M; British Heart Foundation Health Promotion Research Group. Coronary Heart Disease Statistics, 2007 ed:10-220. http://www.bhforg.uk/ hearthealth/statistics/heart-statistics-publications.aspx

11. Allender S, Peto V, Scarborough P, Kaur A, Rayner M; British Heart Foundation Health Promotion Research Group. Coronary Heart Disease Statistics, 2008 ed:10-220. http://www.bhf.org.uk/ hearthealth/statistics/heart-statistics-publications.aspx

12. Allender $S$, Scarborough $P$, Peto $V$, Rayner $M$; British Heart Foundation Health Promotion Research Group. Leal J, LuengoFernandez R, Gray A; Health Economics Research Center. European Cardiovascular Disease Statistics, 2008 ed:7-112. http://www.bhf.org.uk/heart-health/statistics/heart-statisticspublications.aspx

13. Directorate General Primary Healthcare Services, The Ministry of Health of Turkey $(\mathrm{MoH})$. Prevention and control program for cardiovascular diseases. MoH publication no: 743. Ankara 2009;1-113. 
14. Turkish Society of Cardiology, Refik Saydam Hygiene Center (School of Public Health) and some other occupational societies. 'National Heart Health Policy Document'. (Draft in Turkish). Online Referencing, http://www.tkd.org.tr/pages.asp?pg=276 (2007, accessed April 2011).

15. Onat A. 'The prevalence of coronary heart disease, new coronary events and mortality in Turkish adults'. TEKHARF 2009 study. (In Turkish). Online Referencing, http://tekharf.org/images/2009/ bolum2.pdf (2009, accessed April 2011).

16. Onat $A$, Uğur $M$, Tuncer $M$, Ayhan E, Kaya Z, Küçükdurmaz Z, Bulur $\mathrm{S}$, Kaya H. Age at death in the Turkish Adult Risk Factor Study: Temporal trend and regional distribution at 56,700 person-years' follow-up. (In Turkish). Turk Kardiyol Dern Ars 2009;37:155-160.

17. Müller-Nordhorn J, Binting $S$, Roll $S$, Willich SN. An update on regional variation in cardiovascular mortality within Euroupe. Eur Heart J 2008;29:1316-1326.

18. Onat A, Can G. 'Relative risk of independent predictors of coronary heart disease in Turkish population' TEKHARF 2009 study. (In Turkish). Online Referencing http://tekharf.org/images/2009/bolum3.pdf (2009, accessed April 2011).

19. Mollahaliloğlu S, Bora-Başara B, Eryılmaz Z; Refik Saydam Hygiene Center, School of Public Health, on behalf of The Ministry of Health of Turkey $(\mathrm{MoH})$. Health Statistics Yearbook, 2009. MoH publication no: 824. Ankara, 2011:1-138.

20. Onat A. Risk factors and cardiovascular disease in Turkey. Atherosclerosis 2001:156:1-10.

21. Onat A. Lipids, Lipoproteins and Apolipoproteins Among Turks, and Impact on Coronary Heart Disease - Invited Review. Anadolu Kardiyol Derg 2004;4:236-245

22. Mahley RW, Palaoğlu KE, Atak Z, Dawson-Pepin J, Langlois AM, Cheung V, Onat H, Fulks P, Mahley LL, Vakar F, et al. Turkish Heart Study: Lipids, lipoproteins, and apolipoproteins. J Lipid Res 1995;36:839-859.

23. Mahley RW, Mahley LL, Bersot TP, Pepin GM, Palaoğlu KE. The Turkish Lipid Problem: Low Levels of High Density Lipoproteins. Turk J Endocr Metab 2002;1:1-12. http://www.turkjem.org/ sayilar/21/1-12.pdf

24. Arslan İnce FD, Atay A, Köseoğlu M, Yeşil M, Deveci E. Relationship between severity of coronary artery disease and apolipoprotein $\mathrm{E}$ gene polymorphism. Anadolu Kardiyol Derg 2010;10:202-208.

25. Leal J, Luengo-Fernandez R, Gray A, Petersen S, Rayner M. Economic burden of cardiovascular diseases in the enlarged European Union. Eur Heart J 2006;27:1610-1619.

26. WHO/Europe. 'European health for all database (HFA-DB)'. Online Referencing, http://data.euro.who.int/hfadb/ (1970-2010, accessed April 2011).

27. European Comission. Health in the European Union 2006, Special EUROBAROMETER 272. 2007;13-16.

28. Altun B, Arici M, Nergizoğlu G, Derici U, Karatan O, Turgan C, Sindel S, Erbay B, Hasanoğlu E, Cağlar S; for the Turkish Society of Hypertension and Renal Diseases. Prevalence, awareness, treatment and control of hypertension in Turkey (the PatenT study) in 2003. J Hypertens 2005;23:1817-1823.

29. WHO. Global Infobase Online. 'International Comparisons'. Online Referencing, https://apps.who.int/infobase/Comparisons. aspx (2010, accessed May 2011).

30. International Diabetes Federation (IDF). 'Prevalence estimates of diabetes (20-79 years), for 2010'. IDF Diabetes Atlas (fourth edition, 2009), Online Referencing, http://archive.diabetesatlas. org/map (2009, accessed May 2011).

31. Google world data explorer. World Bank, World Development Indicators: World view. 'GNI per capita in PPP Dollars' Last updated on April 21, 2011, Online Referencing, http://www.google.com/publicdata/explore?ds=d5bncppjof8f9_\& ctype=|\&met_y=sp_ado_tfrt\&hl=en_US\&dl=en_US\#ctype=|\&strail=f alse\&nselm=h\&met_y=ny_gnp_pcap_pp_cd\&scale_y=lin\&ind_y=fal se\&rdim=country\&idim=country:TUR\&ifdim=country\&tdim=true\&h =en\&dl=en_US (2009, accessed April 2011).
32. The World Bank. Data, indicators. 'GNIpc in PPP Dollars (current international \$).' Online Referencing, http://data.worldbank. org/indicator/NY.GNP.PCAP.PP.CD/countries/1W-Z7-TR-DE-GB?display=graph $(2009$, accessed April 2011).

33. Yasue $H$, Nakagawa $H$, Itoh T, Harada E, Mizuno Y. Coronary artery spasm-clinical features, diagnosis, pathogenesis, and treatment. J Cardiol 2008;51:2-17.

34. Johnson BD, Shaw LJ, Pepine CJ, Reis SE, Kelsey SF, Sopko G, Rogers WJ, Mankad S, Sharaf BL, Bittner V, Bairey Merz CN. Persistent chest pain predicts cardiovascular events in women without obstructive coronary artery disease: results from the NIH-NHLBI-sponsored Women's Ischaemia Syndrome Evaluation (WISE) study. Eur Heart $J$ 2006:27:1387-1389.

35. Shaw LJ, Merz CN, Pepine CJ, Reis SE, Bittner V, Kip KE, Kelsey SF, Olson M, Johnson BD, Mankad S, Sharaf BL, Rogers WJ, Pohost GM Sopko G. Women's Ischemia Syndrome Evaluation (WISE) Investigators. The economic burden of angina in women with suspected ischemic heart disease: results from the National Institutes of Health-National Heart, Lung, and Blood Institute-sponsored Women's Ischemia Syndrome Evaluation. Circulation 2006;114:894-904.

36. Lerman A, Sopko G. Women and cardiovascular heart disease: clinical implications from the Women's Ischemia Syndrome Evaluation (WISE) Study. Are we smarter? J Am Coll Cardiol 2006;47(3 Suppl):S59-62.

37. Suwaidi JA, Hamasaki S, Higano ST, Nishimura RA, Holmes DR, Lerman A. Long-term follow-up of patients with mild coronary artery disease and endothelial dysfunction. Circulation 2000;101:948-954.

38. Demirkol MO, Yaymaci B, Kurtoglu N, Mutlu, Dindar I. Slow Coronary Flow: Correlations with Myocardial Perfusion Tomography and Coronary Arteriography. Int J Angiol 2003;12:24-28.

39. Erol Ç, Güzelsoy $D$, Koylan N, Nişancı $Y$, Oktay A, Onat A, Özler A, Sansoy V, Soydan I, Tașdemir O, Tokgözoğlu L; on behalf of the Turkish Society of Cardiology. Guidelines for the diagnosis and treatment of coronary artery disease. (In Turkish). Online Referencing http://www.tkd.org.tr/kilavuz/k06.htm (1998, accessed May 2011).

40. Sadeghi MM, Glover DK, Lanza GM, Fayad ZA, Johnson LL. Imaging Atherosclerosis and Vulnerable Plaque. J Nucl Med 2010;51(Suppl):51-65.

41. Tsimikas S, Shaw PX. Non-invasive imaging of vulnerable plaques by molecular targeting of oxidized LDL with tagged oxidation-specific antibodies. J Cell Biochem Suppl 2002;39:138146.

42. Davies JR, Rudd JH, Weissberg PL. Molecular and Metabolic Imaging of Atherosclerosis. J Nucl Med 2004;45:1898-1907.

43. Weissberg PL. Noninvasive imaging of atherosclerosis: the biology behind the pictures. J Nucl Med 2004;45:1794-1795.

44. Little WC, Constantinescu M, Applegate RJ, Kutcher MA, Burrows MT, Kahl FR, Santamore WP. Can coronary angiography predict the site of a subsequent myocardial infarction in patients with mild to moderate coronary artery disease? Circulation 1988;78:1157-1166.

45. Kersten JR, Pagel PS, Chilian WM, Warltier DC. Multifactorial basis for coronary collateralization: a complex adaptive response to ischemia. Cardiovasc Res 1999:43:44-57.

46. Alderman E, Corley SD, Fisher LD, Chaitman BR, Faxon DP, Foster ED, Killip T, Sosa JA, Bourassa MG; CASS Participating Investigators and Staff. Five-year angiographic follow-up of factors associated with progression of coronary artery disease in the Coronary Artery Surgery Study (CASS). J Am Coll Cardiol 1993;22:1141-1154.

47. Ambrose JA, Tannenbaum MA, Alexopoulos D, Hjemdahl-Monsen CE, Leavy J, Weiss M, Borrico S, Gorlin R, Fuster V. Angiographic progression of coronary artery disease and the development of myocardial infarction. J Am Coll Cardiol 1988;12:56-62.

48. Chopra V, Flanders SA, Froehlich JB, Lau WC, Eagle KA. Perioperative Practice:Time to Throttle Back. Ann Intern Med 2010;152:47-51.

49. Blumenthal RS, Cohn G, Schulman SP. Medical Therapy Versus Coronary Angioplasty in Stable Coronary Artery Disease: A Critical Review of the Literature. J Am Coll Cardiol 2000;36:668-673. 
50. CASS Principal Investigators and Their Associates. Coronary Artery Surgery Study (CASS): A Randomized Trial of Coronary Artery Bypass Surgery, Survival data. Circulation 1983;68:939-950.

51. Alderman EL, Bourassa MG, Cohen LS, Davis KB, Kaiser GG, Killip T, Mock MB, Pettinger $M$, Robertson TL. Ten -Year Follow-up of Survival and Myocardial Infarction in the Randomized Coronary Artery Surgery Study. Circulation 1990;82:1629-1646.

52. Rogers WJ, Coggin CJ, Gersh BJ, Fisher LD, Myers WO, Oberman A Sheffield LT. Ten-Year Follow-Up of Quality of Life in Patients Randomized to Receive Medical Therapy or Coronary Artery Bypass Graft Surgery. The Coronary Artery Surgery Study (CASS). Circulation 1990;82:1647-1658.

53. Parisi AF, Folland ED, Hartigan PM. A comparison of angioplasty with medical therapy in the treatment of single-vessel coronary artery disease. Veterans Affairs ACME Investigators. N Engl J Med 1992;326:10-16.

54. Folland ED, Hartigan P, Parisi AF. Evaluation of exercise thallium scintigraphy versus exercise electrocardiography in predicting survival outcomes and morbid cardiac events in patients with single- and double-vessel disease. Findings from the Angioplasty Compared to Medicine (ACME) Study. J Am Coll Cardiol 1997;30:1256-1263.

55. Parisi AF, Hartigan PM, Folland ED; for the Veterans Affairs ACME Investigators. Percutaneous Transluminal Coronary Angioplasty Versus Medical Therapy for Stable Angina Pectoris: Outcomes for Patients With Double-Vessel Versus Single-Vessel Coronary Artery Disease in a Veterans Affairs Cooperative Randomized Trial fn1 Circulation 1997;29:1505-1511.

56. Hueb WA, Bellotti $G$, de Oliveira $S A$, Arie $S$, de Albuquerque $C P_{\text {, }}$ Jatene $A D$, Pileggi $F$. The medicine, angioplasty or surgery study (MASS): a prospective, randomized trial of medical therapy balloon angioplasty or bypass surgery for single proximal left anterior descending artery stenoses. J Am Coll Cardiol 1995;26:1600-1605.

57. Hueb W, Soares PR, Gersh BJ, Cesar LAM, Luz PL, Puig LB, Martinez EM, Oliveira SA, Ramires JAF. The Medicine, Angioplasty, or Surgery Study (MASS-II): A Randomized Controlled Clinical Trial of Three Therapeutic Strategies For Multivessel Coronary Artery Disease, OneYear Results. J Am Coll Cardiol 2004:43:1743-1751.

58. Hueb W, Lopes NH, Gersh BJ, Soares P, Machado LAC, Jatene FB, Oliveira SA, Ramires JA. Five-Year Follow-Up of The Medicine, Angioplasty, or Surgery Study (MASS-II): A Randomized Controlled Clinical Trial of 3 Therapeutic Strategies For Multivessel Coronary Artery Disease. Circulation 2007; 115:1082-1089.

59. Hueb W, Lopes N, Gersh BJ, Soares PR, Ribeiro EE, Pereira AC, Favarato D, Rocha ASC, Hueb AC, Ramires JA. Ten-Year Follow-Up Survival of The Medicine, Angioplasty, or Surgery Study (MASS-II): A Randomized Controlled Clinical Trial of 3 Therapeutic Strategies For Multivessel Coronary Artery Disease. Circulation 2010;122:949-957.

60. Davies RF, Goldberg AD, Forman S, Pepine CJ, Knatterud GL, Geller N, Sopko G, Pratt C, Deanfield J, Conti CR. Asymptomatic Cardiac Ischemia Pilot (ACIP) Study Two-Year Follow-Up, Outcomes of Patients Randomized to Initial Strategies of Medical Therapy Versus Revascularization. Circulation 1997:95:2037-2043.

61. Pitt $B$, Waters $D$, Brown $W V$, van Boven $A J$, Schwartz $L$, Title $L M$, Eisenberg D, Shurzinske L, McCormick LS. Aggressive lipid-lowering therapy compared with angioplasty in stable coronary artery disease. Atorvastatin versus Revascularization Treatment Investigators. N Engl J Med 1999;341:70-76.

62. Serruys PW, Unger F, Sousa JE, Jatene A, Bonnier HJ, Schönberger JP, Buller N, Bonser R, van den Brand MJ, van Herwerden LA, Morel $M A$, van Hout BA; Arterial Revascularization Therapies Study Group. Comparison of coronary artery bypass surgery and stenting for the treatment of multivessel disease. N Engl J Med 2001;344:117-124.

63. Legrand VM, Serruys PW, Unger F, van Hout BA, Vrolix MC, Fransen GM, Nielsen TT, Paulsen PK, Gomes RS, deq Ueiroz e Melo JM, Neves JP, Lindeboom W, Backx B; Arterial Revascularization Therapy Study (ARTS) Investigators. Three-year outcome after coronary stenting versus bypass surgery for the treatment of multivessel disease. Circulation 2004;109:1114-1120.
64. Serruys PW, Ong AT, van Herwerden LA, Sousa JE, Jatene $A$, Bonnier JJ, Schönberger JP, Buller N, Bonser R, Disco C, Backx B, Hugenholtz $P G$, Firth $B G$, Unger $F$. Five-year outcomes after coronary stenting versus bypass surgery for the treatment of multivessel disease: the final analysis of the Arterial Revascularization Therapies Study (ARTS) randomized trial. J Am Coll Cardiol 2005;46:575-581.

65. Serruys PW, Onuma Y, Garg S, Vranckx P, De Bruyne B, Morice MC, Colombo A, Macaya C, Richardt G, Fajadet J, Hamm C, Schuijer M, Rademaker T, Wittebols K, Stoll HP; ARTS II Investigators. 5-Year clinical outcomes of the ARTS II (Arterial Revascularization Therapies Study II) of the Sirolimus-Eluting Stent in the Treatment of Patients With Multivessel De Novo Coronary Artery Lesions. J Am Coll Cardiol 2010:55:1093-1101.

66. Henderson RA, Pocock SJ, Clayton TC, Knight R, Fox KA, Julian DG, Chamberlain DA; Second Randomized Intervention Treatment of Angina (RITA-2) Trial Participants. Seven-year outcome in the RITA-2 trial: coronary angioplasty versus medical therapy. J Am Coll Cardiol 2003:42:1161-1170.

67. Boden WE, O'Rourke RA, Teo KK, Hartigan PM, Maron DJ, Kostuk WJ, Knudtson $M$, Dada $M$, Casperson $P$, Harris CL, Chaitman BR, Shaw L, Gosselin G, Nawaz S, Title LM, Gau G, Blaustein AS, Booth DC, Bates ER, Spertus JA, Berman DS, Mancini GB, Weintraub WS; COURAGE Trial Research Group. Optimal medical therapy with of without $\mathrm{PCl}$ for stable coronary disease. N Engl J Med. 2007;356:1503-1516

68. Shaw LJ, Berman DS, Maron DJ, Mancini GBJ, Hayes SW, Hartigan PM, Weintraub WS, O'Rourke RA, Dada M, Spertus JA, Chaitman BR, Friedman J, Slomka P, Heller GV, Germano G, Gosselin G, Berger P, Kostuk WJ, Schwartz RG, Knudtson M, Veledar E, Bates ER, McCallister B, Teo KK, Boden WE; COURAGE Investigators. Optimal medical therapy with or without percutaneous coronary intervention to reduce ischemic burden: results from the Clinical Outcomes Utilizing Revascularization and Aggressive Drug Evaluation (COURAGE) trial nuclear substudy. Circulation 2008;117:1283-1291.

69. Booth J, Clayton T, Pepper J, Nugara F, Flather M, Sigwart U, Stables $\mathrm{RH}$; on behalf of the SoS Investigators. Randomized, controlled trial of coronary artery bypass surgery versus percutaneous coronary intervention in patients with multivessel coronary artery disease, sixyear follow-up from the Stent tor Surgery trial (SoS). Circulation 2008;118:381-388.

70. BARI 2D Study Group, Frye RL, August P, Brooks MM, Hardison RM, Kelsey SF, MacGregor JM, Orchard TJ, Chaitman BR, Genuth SM, Goldberg SH, Hlatky MA, Jones TL, Molitch ME, Nesto RW, Sako EY, Sobel BE. A randomized trial of therapies for type 2 diabetes and coronary artery disease. N Engl J Med 2009;360:2503-2515.

71. Rutter MK, Nesto RW. The BARI 2D study: A randomised trial of therapies for type 2 diabetes and coronary artery disease. Diabetes and Vascular Disease Research 2010;7:69-72.

72. Silbur S, Albertsson P, Avile's F, Camici PG, Colombo A, Hamm C,Jørgensen E, Marco J, Nordrehaug JE, Ruzyllo W, Urban P, Stone GW, Wijns W; Task Force for Percutaneous Coronary Interventions of the European Society of Cardiology. Guidelines for percutaneous coronary interventions. The Task Force for Percutaneous Coronary Interventions of the European Society of Cardiology. Eur Heart J 2005;26:804-847

73. Patel MR, Dehmer GJ, Hirshfeld JW, Smith PK, Spertus JA; American College of Cardiology Foundation Appropriateness Criteria Task Force; Society for Cardiovascular Angiography and Interventions: Society of Thoracic Surgeons; American Association for Thoracic Surgery: American Heart Association, and the American Society of Nuclear Cardiology Endorsed by the American Society of Echocardiography; Heart Failure Society of America; Society of Cardiovascular Computed Tomography. ACCF/SCAI/STS/ AATS/AHA/ASNC 2009 Appropriateness Criteria for Coronary Revascularization: a report by the American College of Cardiology Foundation Appropriateness Criteria Task Force, Society for Cardiovascular Angiography and Interventions, Society of Thoracic Surgeons, American Association for Thoracic Surgery, American Heart Association, and the American Society of Nuclear Cardiology 
Endorsed by the American Society of Echocardiography, the Heart Failure Society of America, and the Society of Cardiovascular Computed Tomography. J Am Coll Cardiol 2009;53:530-553.

74. Task Force on Myocardial Revascularization of the European Society of Cardiology (ESC) and the European Association for CardioThoracic Surgery (EACTS); European Association for Percutaneous Cardiovascular Interventions (EAPCI), Wijns W, Kolh P, Danchin N, Di Mario C, Falk V, Folliguet T, Garg S, Huber K, James S, Knuuti J, Lopez-Sendon J, Marco J, Menicanti L, Ostojic M, Piepoli MF, Pirlet C, Pomar JL, Reifart N, Ribichini FL, Schalij MJ, Sergeant P, Serruys PW, Silber S, Sousa Uva M, Taggart D. Guidelines on myocardial revascularization. Eur Heart J 2010;31:2501-2555.

75. Başoğlu T. 'Developements in Multimodality Imaging in Cardiology, An Overview'. A speech in 23th National Nuclear Medicine Congress Izmir, 2011, Online Referencing, http://dds.mediasite.com/mediasite/SilverlightPlayer/Default.aspx? peid $=5118281604 c 1427$ faea76584008c1f4a1d (2011, accessed June 2011).

76. Gibbons RJ, Abrams J, Chatterjee K, Daley J, Deedwania PC, Douglas JS, Ferguson TB Jr, Fihn SD, Fraker TD Jr, Gardin JM, O'Rourke RA, Pasternak RC, Williams SV, Gibbons RJ, Alpert JS, Antman EM, Hiratzka LF, Fuster V, Faxon DP, Gregoratos G, Jacobs AK, Smith SC $\mathrm{Jr}$; American College of Cardiology; American Heart Association Task Force on Practice Guidelines. Committee on the Management of Patients with Chronic Stable Angina. ACC/AHS 2002 guideline update for the management of patients with chronic stable anginasummary article: a report of the American College of Cardiology/American Heart Association Task Force on Practice Guidelines (Committee on the Management of Patients with Chronic Stable Angina). Circulation 2003;107:149-158.

77. Fox K, Garcia M, Ardissino D, Buszman P, Camici PG, Crea F, Daly C, De Backer G, Hjemdahl P, Lopez-Sendon J, Marco J, Morais J, Pepper J, Sechtem U, Simoons M, Thygesen K, Priori SG, Blanc JJ, Budaj A, Camm J, Dean V, Deckers J, Dickstein K, Lekakis J, McGregor K, Metra M, Morais J, Osterspey A, Tamargo J, Zamorano JL; Task Force on the Management of Stable Angina Pectoris of the European Society of Cardiology; ESC Committee for Practice Guidelines (CPG). Guidelines on the management of stable angina pectoris: executive summary. The Task Force on the Management of Stable Angina Pectoris of the European Society of Cardiology. Eur Heart J 2006;27:1341-1381.

78. Gibbons RJ. Noninvasive diagnosis and prognosis assessment in chronic coronary artery disease: stress testing with and without imaging perspective. Circ Cardiovasc Imaging 2008;1:257-269.

79. Greenland P, Alpert JS, Beller GA, Benjamin EJ, Budoff MJ, Fayad ZA, Hlatky MA, Hodgson JM, Kushner FG, Lauer MS, Shaw LI, Smith SC Jr, Weintraub WS. 2010 ACCF/AHA guideline for assessment of cardiovascular risk in asymptomatic adults: executive summary. J Am Coll Cardiol 2010:56:2182-2199.

80. Akıncıoğlu Ç, Atasever T, Caner B, Çapa Kaya G, Kıraç S, Ünlü M. Turkish Society of Nuclear Medicine Nuclear Cardiology Task Group. Nuclear Cardiology-Procedure Guidelines. (In Turkish). Turk J Nucl Med 2001;10(Suppl):41-56.

81. Gibbons RJ, Balady GJ, Timothy BJ, Chaitman BR, Fletcher GF Froelicher VF, Mark DB, McCallister BD, Mooss AN, O'Reilly MG, Winters WL, Gibbons RJ, Antman EM, Alpert JS, Faxon DP, Fuster $V_{\text {, }}$ Gregoratos G, Hiratzka LF, Jacobs AK, Russell RO, Smith SC; American College of Cardiology/American Heart Association Task Force on Practice Guidelines. Committee to Update the 1997 Exercise Testing Guidelines. ACC/AHA 2002 guideline update for exercise testing: A report of the American College of Cardiology/American Heart Association Task Force on Practice Guidelines (Committee to Update the 1997 Exercise Testing Guidelines). J Am Coll Cardiol 2002:40:1531-1540.

82. Underwood SR, Godman B, Salyani S, Ogle JR, Ell PJ. Economics of Myocardial Perfusion Imaging in Europe-The EMPIRE study. Eur Heart J 1999; 20:157-166.
83. Sicari R, Nihoyannopoulos $P$, Evangelista A, Kasprzak J, Lancellotti $P_{\text {, }}$ Poldermans D, Voigt JU, Zamorano JL; European Association of Echocardiography. Stress echocardiography expert consensus statement: European Association of Echocardiograph (EAE) (a registered branch of the ESC). Eur J Echocardiogr 2008;9:415-437.

84. Davidavicius G, Kowalski M, Williams RI, D’Hooge J, Di Salvo G Pierre- Justin G, Claus P, Rademakers F, Herregods MC, Fraser AG, Pierard LA, Bijnens B, Sutherland GR. Can Regional strain and strain rate measurement be performed during both dobutamine and exercise echocardiography, and do regional deformation responses differ with different forms of stress testing? J Am Soc Echocardiogr 2003;16:299-308.

85. Mark DB, Berman DS, Budoff MJ, Carr JJ, Gerber TC, Hecht HS, Hlatky MA, Hodgson JM, Lauer MS, Miller JM, Morin RL, Mukherjee $D$, Poon $M$, Rubin GD, Schwartz RS. ACCF/ACR/AHA/NASCI/SAIP/SCAI/SCCT 2010 expert consensus document on coronary computed tomographic angiography: a report of the American College of Cardiology Foundation Task Force on Expert Consensus Documents. J Am Coll Cardiol 2010;55:26632699.

86. Shaw LJ, Narula J. Risk Assessment and Predictive Value of Coronary Artery Disease Testing. J Nucl Med 2009;50:1296-1306.

87. Weustink AC, Mollet NR, Neefjes LA, Meijboom WB, Galema TW, van Mieghem CA, Kyrzopoulous S, Eu RN, Nieman K, Cademartiri F, van Geuns RJ, Boersma E, Krestin GP, de Feyter PJ. Diagnostic accuracy and clinical utility of noninvasive testing for coronary artery disease. Ann Intern Med 2010;152:630-639.

88. Hachamovitch R, Hayes SW, Friedman JD, Cohen I, Berman DS. Comparison of the Short-Term Survival Benefit Associated With Revascularization Compared With Medical Therapy in Patients With No Prior Coronary Artery Disease Undergoing Stress Myocardial Perfusion Single Photon Emission Computed Tomography. Circulation 2003;107:2900-2907

89. Marwick TH, Shaw LJ, Lauer MS, Kesler K, Hachamovitch R, Heller GV, Travin MI, Williams R, Borges-Neto S, Berman DS, Miller DD. The noninvasive prediction of cardiac mortality in men and women with known or suspected coronary artery disease. Economics of Noninvasive Diagnosis (END) Study Group. Am J Med 1999:106:172-178.

90. Mowatt $G$, Brazzelli $M$, Gemmell $H$, Hillis GS, Metcalfe $M$, Vale Li Aberdeen Technology Assessment Group. Systematic review of the prognostic effectiveness of SPECT myocardial perfusion scintigraphy in patients with suspected or known coronary artery disease and following myocardial infarction. Nucl Med Comm 2005;26:217-229.

91. Schenker MP, Dorbala S, Hong EC, Rybicki FJ, Hachamovitch R, Kwong RY, Di Carli MF. Interrelation of coronary calcification, myocardial ischemia, and outcomes in patients with intermediate likelihood of coronary artery disease: a combined positron emission tomography/computed tomography study. Circulation 2008; 117:1693-1700.

92. Uebleis C, Becker A, Griesshammer I, Cumming P, Becker C, Schmidt $M$, Bartenstein P, Hacker M. Stable Coronary Artery Disease: Prognostic Value of Myocardial Perfusion SPECT in Relation to Coronary Calcium Scoring-Long-term Follow-up1. Radiology 2009:252:682-690.

93. Schuijf JD, Wijns W, Jukema JW, Decramer I, Atsma DE, de Roos A, Stokkel MP, Dibbets-Schneider P, van der Wall EE, Bax JJ. Acomparative regional analysis of coronary atherosclerosis and calcium score on multislice CT versus myocardial perfusion on SPECT. J Nucl Med 2006;47:1749-1755.

94. Gaemperli O, Schepis T, Valenta I, Koepfli P, Husmann L, Scheffel H, Leschka S, Eberli FR, Luscher TF, Alkadhi H, Kaufmann PA. Functionally relevant coronary artery disease: comparison of 64-section CT angiography with myocardial perfusion SPECT. Radiology 2008;248:414-423.

95. Tamarappoo B, Hachamovitch R. Myocardial Perfusion Imaging Versus CT Coronary Angiography: When to Use Which? J Nucl Med 2011;52:1079-1086. 
96. Kajander S, Joutsiniemi E, Saraste M, Pietilä M, Ukkonen H, Saraste A, Sipilä HT, Teräs $M$, Mäki $M$, Airaksinen J, Hartiala J, Knuuti J. Cardiac positron emission tomography/computed tomography imaging accurately detects anatomically and functionally significant coronary artery disease. Circulation 2010;122:603-613.

97. Shaw LJ, Hachamovitch R, Berman DS, Marwick TH, Lauer MS, Heller GV, Iskandrian AE, Kesler KL, Travin MI, Lewin HC, Hendel RC, Borges-Neto S, Miller DD. The economic consequences of available diagnostic and prognostic strategies for the evaluation of stable angina patients: an observational assessment of the value of precatheterization ischemia. Economics of Noninvasive Diagnosis (END) Multicenter Study Group. J Am Coll Cardiol 1999;33:661-669.

98. Shaw LJ, Heller GV, Travin MI, Lauer M, Marwick T, Hachamovitch R, Berman DS, Miller DD. Cost analysis of diagnostic testing for coronary artery disease in women with stable chest pain. Economics of Noninvasive Diagnosis (END) Study Group. I Nucl Cardiol 1999;6:679-681.

99. Mowatt $G$, Vale L, Brazzelli M, Hernandez R, Murray A, Scott A, Fraser C, McKenzie L, Gemmell H, Hillis G, Metcalfe M. Systematic review of the effectiveness and cost-effectiveness, and economic evaluation, of myocardial perfusion scintigraphy for the diagnosis and management of angina and myocardial infarction. Health Technol Assess 2004;8:1-207.

100. Des Prez RD, Shaw LJ, Gillespie RL, Jaber WA, Noble GL, Soman $P_{\text {, }}$ Wolinsky DG, Williams KA. Costeffectiveness of myocardial perfusion imaging: a summary of the currently available literature. J Nucl Cardiol 2005;12:750-759.

101. Sharples L, Hughes V, Crean A, Dyer M, Buxton M, Goldsmith K Stone D. Cost-effectiveness of functional cardiac testing in the diagnosis and management of coronary artery disease: a randomised controlled trial. The CECaT trial. Health Technol Assess 2007;11:iii-iv, ix-115.

102. Underwood SR, Anagnostopoulos C, Cerqueira M, Ell PJ, Flint EJ, Harbinson M, Kelion AD, Al-Mohammad A, Prvulovich EM, Shaw LJ, Tweddel AC; British Cardiac Society; British Nuclear Cardiology Society; British Nuclear Medicine Society; Royal College of Physicians of London; Royal College of Radiologists. Myocardial perfusion scintigraphy: the evidence. Eur I Nucl Med Mol Imaging 2004;31:261-291.

103. Shaw LJ, Marwick TH, Berman DS, Sawada S, Heller GV, Vasey C, Miller DD. Incremental cost effectiveness of exercise echocardiography versus SPECT imaging for the evaluation of stable chest pain. Eur Heart J 2006;27:2448-2458.

104. Min JK, Kang N, Shaw LJ, Devereux RB, Robinson M, Lin F, Legorreta $A P$, Gilmore A. Costs and clinical outcomes after coronary multidetector CT angiography in patients without known coronary artery disease: comparison to myocardial perfusion SPECT. Radiology 2008;249:62-70.
105. Min JK, Shaw LJ, Berman DS, Gilmore A, Kang N. Costs and clinical outcomes in individuals without known coronary artery disease undergoing coronary computed tomographic angiography from an analysis of Medicare category III transaction codes. Am J Cardiol 2008;102:672-678.

106. Hachamovitch R, Hayes SW, Friedman JD, Cohen I, Berman DS. Stress myocardial perfusion single-photon emission computed tomography is clinically effective and cost effective in risk stratification of patients with a high likelihood of coronary artery disease (CAD) but no known CAD. J Am Coll Cardiol 2004;43:200-208.

107. Underwood SR, Shaw LJ. Anagnostopoulos C, Cerqueira M, Ell PJ, Flint J, Harbinson M, Kelion A, Al Mohammad A, Prvulovich EM. Myocardial perfusion scintigraphy and cost effectiveness of diagnosis and management of coronary heart disease. Heart 2004;90(Suppl):34-36.

108. Yılmaz MB, Büyükkaramıklı NÇ, Çakan N, Kalem Ö, Karan S, Koçak FO, Korkmaz Ş, Çobanoğlu A. A rational cost-assesment system should take risk factors into consideration: an evaluation of package for coronary angiography procedures. (In Turkish). Arch Turk Soc Cardiol 2005;33:276-280.

109. Mozes B, Shabtai E. The appropriateness of performing coronary angiography in two major teaching hospitals in Israel. Int J Quality Health Care 1994;6:245-249.

110. Laupacis A, Feeny D, Detsky AS, Tugwell PX. How attractive does a new technology have to be to warrant adoption and utilization? Tentative guidelines for using clinical and economic evaluations. Can Med Assoc J 1992;146:473-481.

111. Yapı Cı O. Patient Selection Criteria in Myocardial Perfusion Scintigraphy: A Retrospective Analysis of 990 Regionally Referred and Single Center Reported Cases. (In Turkish). Turk J Nucl Med 2010;19:110-117.

112. Tokgözoğlu L, Kaya EB, Erol C, Ergene O; EUROASPIRE III Turkey Study Group. EUROASPIRE III: a comparison between Turkey and Europe. (In Turkish). Arch Turk Soc Cardiol 2010;38:164-172.

113. Unal B, Critchley JA, Capewell S. Modelling the decline in coronary heart disease deaths in England and Wales, 1981-2000: comparing contributions from primary prevention and secondary prevention. BMJ 2005;331:614. 